Article

\title{
Lattice Preferred Orientation and Deformation Microstructures of Glaucophane and Epidote in Experimentally Deformed Epidote Blueschist at High Pressure
}

\author{
Yong Park $®$, Sejin Jung $(\mathbb{D}$ and Haemyeong Jung *(D) \\ Tectonophysics Laboratory, School of Earth and Environmental Sciences, Seoul National University, Seoul 08826, \\ Korea; dark2444@snu.ac.kr (Y.P.); shazabi7@snu.ac.kr (S.J.) \\ * Correspondence: hjung@snu.ac.kr; Tel.: +82-2-880-6733
}

Received: 30 July 2020; Accepted: 9 September 2020; Published: 11 September 2020

\begin{abstract}
To understand the lattice preferred orientation (LPO) and deformation microstructures at the top of a subducting slab in a warm subduction zone, deformation experiments of epidote blueschist were conducted in simple shear under high pressure (0.9-1.5 GPa) and temperature $\left(400-500{ }^{\circ} \mathrm{C}\right)$. At low shear strain $(\gamma \leq 1)$, the [001] axes of glaucophane were in subparallel alignment with the shear direction, and the (010) poles were subnormally aligned with the shear plane. At high shear strain $(\gamma>2)$, the [001] axes of glaucophane were in subparallel alignment with the shear direction, and the [100] axes were subnormally aligned with the shear plane. At a shear strain between $2<\gamma<4$, the (010) poles of epidote were in subparallel alignment with the shear direction, and the [100] axes were subnormally aligned with the shear plane. At a shear strain where $\gamma>4$, the alignment of the (010) epidote poles had altered from subparallel to subnormal to the shear plane, while the [001] axes were in subparallel alignment with the shear direction. The experimental results indicate that the magnitude of shear strain and rheological contrast between component minerals plays an important role in the formation of LPOs for glaucophane and epidote.
\end{abstract}

Keywords: lattice preferred orientation; glaucophane; epidote; deformation experiment; simple shear; dislocation glide; cataclastic flow

\section{Introduction}

Several previous studies have recognized blueschist as one of the representative rocks in the subduction zone at increased depths. This is because the subducting oceanic crust is considered to transform to blueschist-facies metamorphic rock under high pressure (0.5-2.5 GPa) and relatively low temperature $\left(150-550{ }^{\circ} \mathrm{C}\right)$ conditions [1-3]. The blueschist has been reported worldwide in the paleo-subduction zone or active subduction zone [4-6]. Previous geophysical studies have reported that the low-velocity layer of the subduction zone almost coincides with the upper plane of the double seismic zone at the top of the subducting oceanic crust [7-9]. Glaucophane and lawsonite or epidote in blueschist is considered to potentially affect seismic velocity at the top of the subducting oceanic crust $[10,11]$, as these minerals contain a high $\mathrm{H}_{2} \mathrm{O}$ content (as hydroxyl) in their molecular structure [2,12]. Other studies have reported that the tremors and low-frequency earthquakes (LFEs) occur near the top of the low-velocity layers $[13,14]$. In addition, researchers have suggested that the lattice preferred orientation (LPO) of glaucophane, one of the elastically anisotropic minerals in blueschist, may affect the trench-parallel seismic anisotropy of the forearc region where the subducting slab has a high dip angle [15-18]. 
To better understand the characteristics of this subduction zone, it is necessary to understand the deformation behavior of the constituent minerals in blueschist. Among these minerals, glaucophane and epidote, recognized as the principal minerals of epidote blueschist, are important at the top of the slab in warm subduction zones. Previous studies on the deformation of natural rocks have suggested several deformation mechanisms for glaucophane; (1) the rigid behavior of glaucophane in eclogitic micaschist [19], (2) rigid body rotation and dynamic recrystallization by dislocation creep in glaucophanite [20], (3) dislocation glide (or slip) in eclogitic micaschist and glaucophane schist [21], (4) dynamic recrystallization by dislocation creep in natural blueschist [17,18], and (5) dissolution-precipitation creep in rocks deformed at high $\mathrm{P} / \mathrm{T}$ conditions with aqueous fluids [22]. For epidote, five deformation mechanisms have been proposed; (1) rigid body rotation for epidote (zoisite) in metabasite rock [23], (2) dislocation glide for epidote (clinozoisite) in eclogite [24,25], (3) either dislocation glide or sliding on the cleavage by fracturing in naturally deformed rocks [26], and (4) rigid body rotation at relatively low shear strain $(\gamma=2)$ and $(5)$ granular flow and a diffusion-assisted grain boundary sliding at relatively high shear strain $(\gamma=4.5$ and 7.5$)$ for epidote (zoisite) product in an experimentally deformed plagioclase matrix [27]. Thus, glaucophane and epidote are likely to be deformed through brittle and ductile behavior based on the results from these previous studies. However, the dominant mechanism in the subducting slab in the subduction zone continues to be debated in the literature.

It is possible to develop the LPOs of glaucophane and epidote in blueschist through these deformation mechanisms. Previous studies have reported several LPOs or slip systems of glaucophane. Several dislocation slip systems of glaucophane were first reported by a transmission electron microscopy (TEM)/high-resolution electron microscopy (HREM) study [21]. Recent studies on natural blueschists have reported three types of LPOs for glaucophane; (1) LPO indicating a (100)[001] slip system (or, point/SL-type LPO) [15-18,28-32], (2) LPO indicating a \{110\}[001] slip system (or, girdle/L-type LPO) [15,16,18,28,31], and (3) LPO indicating a (010)[001] slip system [33]. Although there has been little description on the slip systems of epidote, certain TEM/HREM studies have suggested the easiest slip plane (e.g., [24,34]). There are two types of LPOs for epidote that have recently been reported: one is the LPO indicating a (001)[010] slip system [16,17,28,29,35], and the other is the LPO indicating a $\{101\}[010]$ slip system $[16,30,33,35]$. Although LPOs of glaucophane and epidote have been reported, there is little clarity as to the deformation mechanisms that developed their LPOs.

This study conducts deformation experiments for epidote blueschist in simple shear under high pressure (0.9-1.5 GPa) and temperature $\left(400-500{ }^{\circ} \mathrm{C}\right)$, to understand the development of LPOs and deformation mechanisms of glaucophane and epidote in the conditions prevailing over the subducting slab in a warm subduction zone.

\section{Methods}

\subsection{Starting Material}

The starting material was a natural epidote blueschist-facies rock collected from the Voltri massif in the western Alps, Italy. This was a massive fine-grained rock with a small grain size (average $\sim 30 \mu \mathrm{m}$, Figure 1a). There was no clear foliation and lineation in the hand specimen and thin section. The blueschist was mainly composed of Na-amphibole (glaucophane, $\sim 55 \%$ ), epidote $(\sim 15 \%)$, albite $(\sim 15 \%)$, titanite $(\sim 5 \%)$, chlorite $(\sim 5 \%)$, and garnet (almandine, $\sim 5 \%)$. The starting material underwent peak metamorphic conditions at a pressure of 22-28 kbar and a temperature of $460-500{ }^{\circ} \mathrm{C}$ and was re-equilibrated at a pressure of $10-15 \mathrm{kbar}$ and a temperature of $450-500{ }^{\circ} \mathrm{C}$ [36]. The mineral composition of the starting material was measured with a JEOL JXA-8100 electron probe X-ray microanalyzer at the Center for Research Facilities at Gyeongsang National University (GNU), South Korea. The measurement conditions included an accelerating voltage of $15 \mathrm{kV}$, a current of $10 \mathrm{nA}$, and a $5 \times 5 \mu^{2}$ beam size. The Na-amphibole was classified as pure glaucophane, represented by the formula $\mathrm{Na}_{2.0}\left[\left(\mathrm{Mg}_{1.7} \mathrm{Fe}^{2+}{ }_{1.3}\right)\left(\mathrm{Ca}_{0.04} \mathrm{Mn}_{0.01}\right) \mathrm{Al}_{1.8} \mathrm{Fe}^{3+}{ }_{0.09}\right] \mathrm{Si}_{8.1} \mathrm{O}_{22}(\mathrm{OH})_{2}$. The epidote was classified as 
$\mathrm{Ep}_{50.4} \mathrm{CzO}_{49.6}$, represented by the formula $\mathrm{Ca}_{2.0} \mathrm{Al}_{2.0}\left(\mathrm{Fe}^{3+}{ }_{0.50} \mathrm{Al}^{\mathrm{VI}}{ }_{0.49}\right)\left(\mathrm{Si}_{1.0} \mathrm{O}_{4}\right)\left(\mathrm{Si}_{2.0} \mathrm{O}_{7}\right) \mathrm{O}(\mathrm{OH})(\mathrm{Table} 1)$. The backscattered electron (BSE) image of the starting material illustrates the subhedral shape of the constituent minerals with an absence of fractures and few cleavages (Figure 1b). Most grain boundaries of glaucophane are irregular and curved, while some glaucophane grains represent the retrograded rim from $\mathrm{Na}$-rich to $\mathrm{NaCa} / \mathrm{Ca}$-rich, after having undergone somewhat retrograde metamorphism [37]. Epidote minerals also possess irregular grain boundaries and are relatively larger than glaucophane minerals.
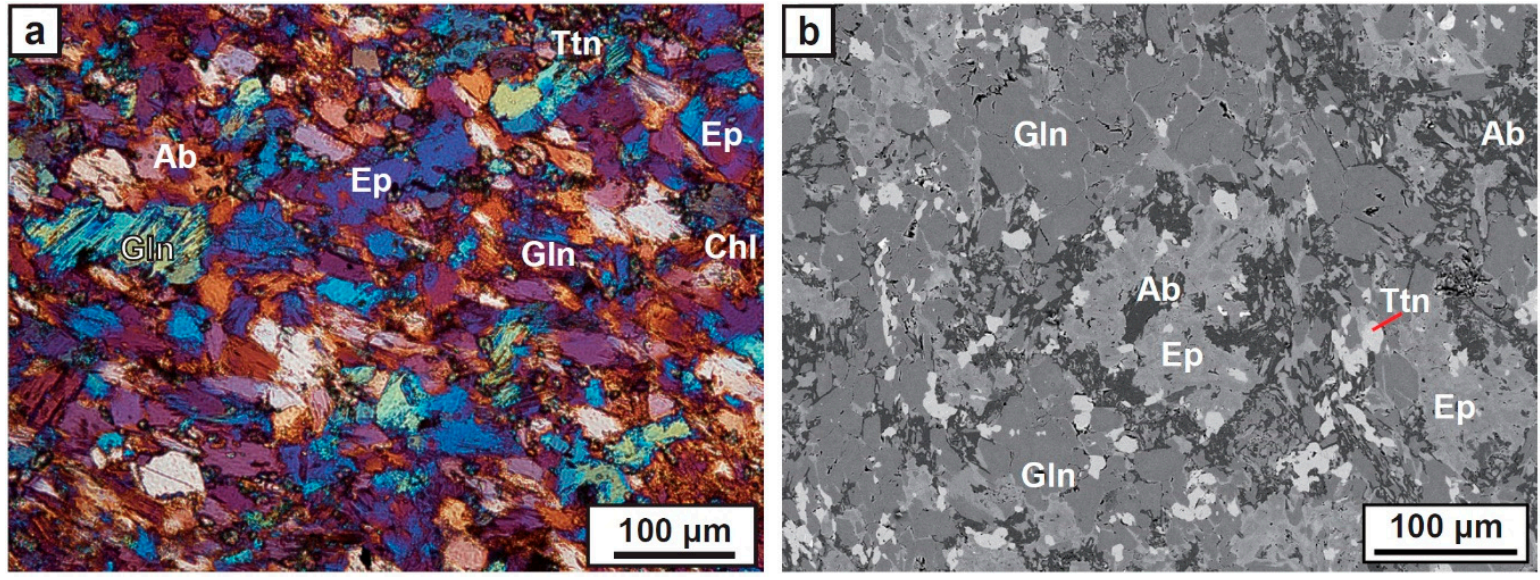

Figure 1. (a) Optical photomicrograph (XPL) with retardation plate $(\lambda=530 \mathrm{~nm})$ and (b) backscattered electron (BSE) image of the starting material (massive fine-grained epidote blueschist-facies rock). The average grain size of constituent minerals was $\sim 30 \mu \mathrm{m}$. Gln: glaucophane, Ep: epidote, Ttn: titanite, Ab: albite, and Chl: chlorite.

\subsection{Deformation Experiment in Simple Shear}

Deformation experiments of epidote blueschist were conducted using a modified Griggs apparatus at the Tectonophysics Laboratory, School of Earth and Environmental Sciences (SEES) at Seoul National University (SNU), Seoul, South Korea. Figure 2 presents the sample assembly designed for the deformation experiment in simple shear. As there was no clear foliation and lineation in the starting material, the sample was core-drilled in an arbitrary orientation in the same direction as a cylindrical rod with a $3.15 \mathrm{~mm}$ diameter and cut at $45^{\circ}$ to $\sim 400 \mu \mathrm{m}$ thick, for the simple shear experiment. The sample was sandwiched between alumina pistons cut at $45^{\circ}$ in the maximum principal stress $\left(\sigma_{1}\right)$ direction, keeping the same orientation for all experiments. Weak $\mathrm{CsCl}$ or $\mathrm{NaCl}$ was used as a pressure medium. A thin Ni foil, a strain marker, was inserted in the middle of the sample perpendicular to the shear plane. Temperature was monitored using two thermocouples $\left(\mathrm{Pt}_{70}-\mathrm{Rh}_{30}\right.$ and $\left.\mathrm{Pt}_{94}-\mathrm{Rh}_{6}\right)$ near the top and bottom of the specimen. The confining pressure and temperature were raised to the target pressure $(0.9-1.5 \mathrm{GPa})$ and temperature $\left(400-500^{\circ} \mathrm{C}\right)$ within $\sim 10 \mathrm{~h}$ and $\sim 30 \mathrm{~min}$, respectively. The sample was deformed by moving the tungsten carbide (WC) and alumina pistons at a constant speed $\left(\sim 8.7 \times 10^{-5} \mathrm{~mm} \cdot \mathrm{s}^{-1}\right)$. Following the deformation experiment, the sample was quenched to room temperature by shutting off the power to preserve microstructures developed during experiments. The confining pressure was decreased to room pressure in the same length of time that it took to increase and reach the target pressure. 
Table 1. The representative composition of glaucophane and epidote in the starting material.

\begin{tabular}{|c|c|c|c|c|c|c|c|c|c|c|c|c|}
\hline Element & $\mathrm{SiO}_{2}$ & $\mathrm{TiO}_{2}$ & $\mathrm{Al}_{2} \mathrm{O}_{3}$ & $\mathrm{Cr}_{2} \mathrm{O}_{3}$ & $\mathrm{FeO}$ & $\mathrm{MgO}$ & $\mathrm{CaO}$ & $\mathrm{MnO}$ & $\mathrm{Na}_{2} \mathrm{O}$ & $\mathrm{K}_{2} \mathrm{O}$ & $\mathrm{NiO}$ & Total \\
\hline Gln & 57.31 & 0.03 & 10.68 & 0.03 & 11.92 & 8.22 & 0.26 & 0.08 & 7.30 & n.d. & n.d. & 95.84 \\
\hline Ep & 38.02 & 0.00 & 26.76 & n.d. & 7.61 & 0.03 & 23.37 & 0.07 & 0.03 & 0.01 & n.d. & 95.90 \\
\hline Cation & Si & $\mathrm{Ti}$ & Al & $\mathrm{Cr}$ & $\mathrm{Fe}^{2+}$ & $\mathrm{Fe}^{3+}$ & Mg & $\mathrm{Ca}$ & Mn & $\mathrm{Na}$ & $\mathbf{K}$ & Sum \\
\hline Gln & 8.06 & 0.00 & 1.77 & 0.00 & 1.31 & 0.09 & 1.73 & 0.04 & 0.01 & 1.99 & - & 15.01 \\
\hline Ep & 3.01 & 0.00 & 2.49 & - & 0.00 & 0.50 & 0.00 & 1.98 & 0.00 & 0.00 & 0.00 & 7.99 \\
\hline Gln & $\mathrm{Si}[\mathrm{T}]$ & $\mathrm{Ti}[\mathrm{T}]$ & $\mathrm{Al}[\mathrm{T}]$ & $\mathrm{Ti}[\mathrm{C}]$ & $\mathrm{Al}[\mathrm{C}]$ & $\mathrm{Cr}[\mathrm{C}]$ & $\mathrm{Fe}^{2+}[\mathrm{C}]$ & $\mathrm{Fe}^{3+}[\mathrm{C}]$ & $\mathrm{Mg}[\mathrm{C}]$ & $\mathrm{Ca}[\mathrm{C}]$ & $\mathrm{Mn}[\mathrm{C}]$ & - \\
\hline Cal. \# & 8.06 & 0.00 & 0.00 & 0.00 & 1.77 & 0.00 & 1.31 & 0.09 & 1.72 & 0.04 & 0.01 & - \\
\hline Gln & $\mathrm{Fe}^{2+}[\mathrm{B}]$ & $\mathrm{Mg}[\mathrm{B}]$ & $\mathrm{Ca}[\mathrm{B}]$ & $\mathrm{Mn}[\mathrm{B}]$ & $\mathrm{Na}[\mathrm{B}]$ & $\mathrm{Na}[\mathrm{A}]$ & $\mathrm{Ca}[\mathrm{A}]$ & $\mathrm{K}[\mathrm{A}]$ & - & - & - & - \\
\hline Cal. \# & 0.00 & 0.00 & 0.00 & 0.00 & 1.99 & 0.00 & 0.00 & 0.00 & - & - & - & - \\
\hline Ep & $\mathrm{Si}[\mathrm{T}]$ & $\mathrm{Al}^{\mathrm{IV}}[\mathrm{T}]$ & $\mathrm{Ti}[\mathrm{M}]$ & $\mathrm{Cr}[\mathrm{M}]$ & $\mathrm{Al}^{\mathrm{VI}}[\mathrm{M}]$ & $\mathrm{Fe}^{3+}[\mathrm{M}]$ & $\mathrm{Mg}[\mathrm{M}]$ & $\mathrm{Mn}[\mathrm{M}]$ & $\mathrm{Na}[\mathrm{M}]$ & $\mathrm{K}[\mathrm{M}]$ & $\mathrm{Ca}[\mathrm{A}]$ & - \\
\hline Cal. \# & 3.01 & 0.00 & 0.00 & 0.00 & 2.49 & 0.50 & 0.00 & 0.00 & 0.00 & 0.00 & 1.98 & - \\
\hline
\end{tabular}

Gln: glaucophane, Ep: epidote, n.d.: not detected, Cal. \#: the calculated cation values occupying each site in the crystal structure, [T] and [A]: T-site and A-site in amphibole (glaucophane) and epidote crystal structures, $[\mathrm{C}]$ and $[\mathrm{B}]$ : C-site and B-site in amphibole (glaucophane) structure, and [M]: M-site in epidote structure. 


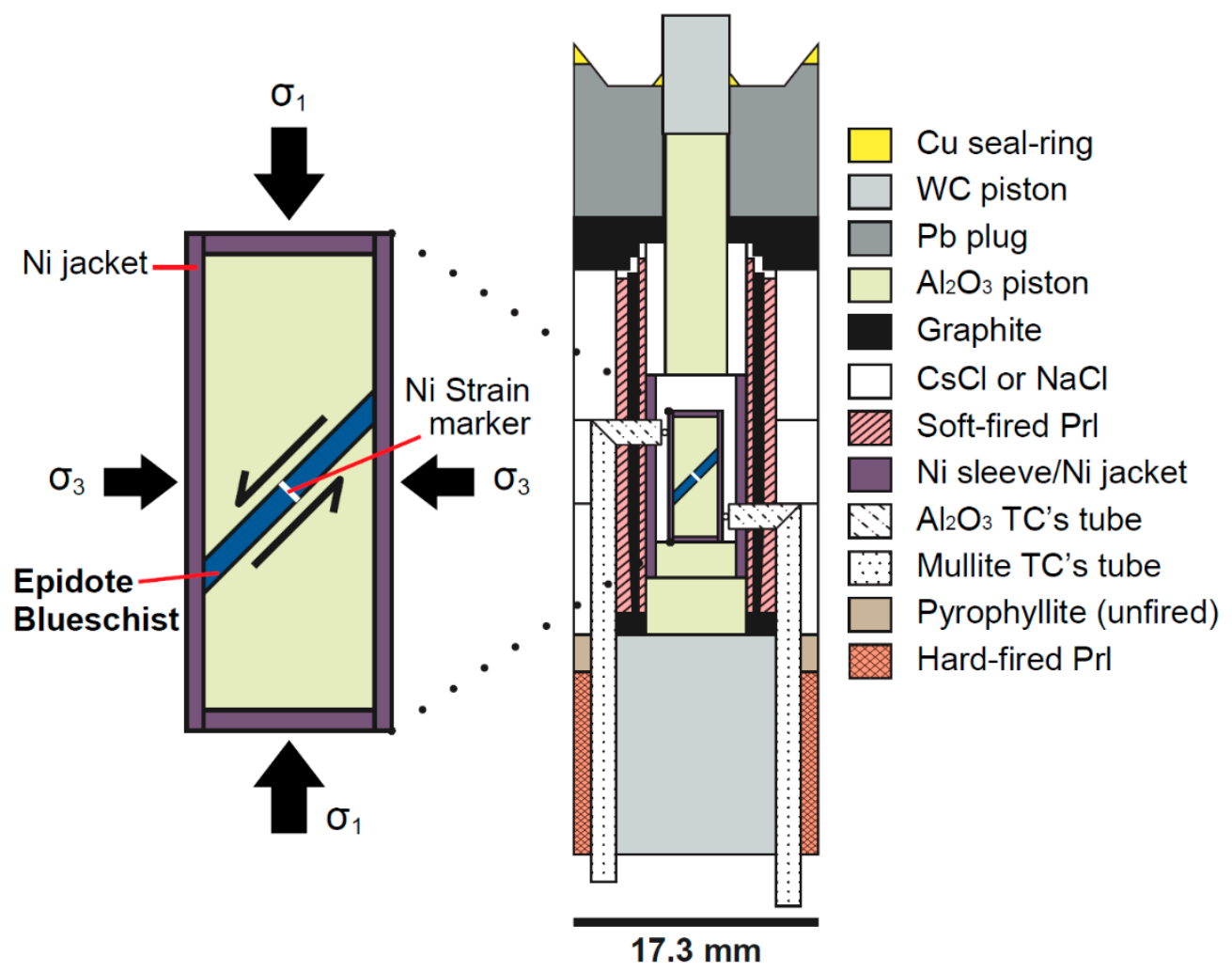

Figure 2. Schematic of sample assembly for the deformation experiment in simple shear. The sample was positioned at $45^{\circ}$ to the maximum principal stress $\left(\sigma_{1}\right)$. A strain marker was placed perpendicular to the shear plane in the middle of the sample.

\subsection{Determination of LPOs of Minerals}

The LPOs of minerals in epidote blueschist were determined using the electron backscattered diffraction (EBSD) technique [38], prior to and after the deformation experiment. To determine the LPOs, we used HKL Technology's EBSD system (Channel 5 software) with a Nordlys II detector attached to the scanning electron microscope (SEM; JEOL JSM 6380) at the SEES in SNU. The LPOs of glaucophane and epidote were measured in the XZ plane of the deformed samples; the $X$ - and $Z$-directions represent the shear direction and direction normal to the shear plane, respectively. Samples were polished using alumina powders, diamond paste of $1 \mu \mathrm{m}$, and Syton $(0.06 \mu \mathrm{m}$ colloidal silica slurry) because the measurement of the LPO of minerals using SEM involved removing the mechanical surface damage using a chemical-mechanical polishing technique [39]. The polished plane was coated with a $\sim 3 \mathrm{~nm}$ thick carbon to prevent charging in the SEM, and the surface was tilted $70^{\circ}$ to the incident electron beam in the chamber. EBSD analysis was conducted under a $20 \mathrm{kV}$ accelerating voltage, a $15 \mathrm{~mm}$ working distance, and a spot size of 60 . For each grain, all EBSD patterns were manually indexed point by point to determine the LPO of the mineral accurately.

\subsection{Observation of the Deformation Microstructures in Minerals}

The observation of deformed samples following the experiments was conducted using field-emission SEM (FE-SEM; JEOL JSM 7100F) at the SEES in SNU. To observe the intracrystalline deformation microstructures in samples, EBSD mapping of deformed grains was conducted using the Oxford Instruments' EBSD system (AZtec v. 3.4 software), with a Symmetry detector attached to the FE-SEM at the SEES in SNU. EBSD analysis was conducted under a $15 \mathrm{kV}$ accelerating voltage, a $25 \mathrm{~mm}$ working distance, a $\sim 3 \mathrm{nA}$ probe current, and a 0.1-0.2 $\mu \mathrm{m}$ step size. Data were subsequently processed using MTEX, a MATLAB toolbox [40], to calculate the local misorientations for textural analysis. This study used the grain reference orientation deviation (GROD) angle map and the kernel 
angle misorientation (KAM) map. The former is a map generated based on the deviation between the mean orientation of a reference point and those of other points. The KAM map is the misorientation less than the predefined threshold value calculated by the mean orientation between a point and its neighbors. The TEM technique was also used to observe dislocation structures in deformed grains. TEM observations under a $300 \mathrm{kV}$ accelerating voltage were carried out using a JEOL JEM-3010 at the National Center for Inter-university Research Facilities (NCIRF) in SNU. Focused ion beam (FIB) foils for TEM investigations were prepared using the FEI Helios 650 at the NCIRF in SNU. The FIB mineral foils were extracted subparallel to the shear direction and shear plane.

\section{Results}

\subsection{Deformation Microstructures after Experiments}

Table 2 summarizes the experimental conditions and results for the deformation experiments on the epidote blueschist. The deformation microstructures of representative samples are shown in Figure 3. Even though we designed and used the sample assembly (Figure 2) for simple shear, there was a small proportion of the pure shear component ( 5-9\%) for all experiments depending on the shear strain magnitude. We quantified the magnitude of the shear strain $(\gamma)$ by the rotational angle of the thin Ni strain marker and/or elongated shapes of grains. In the sample deformed with low shear strain $(\gamma \leq 1)$, most minerals exhibited a similar shape to that of the starting material (Figure 3a,b). Glaucophane grains had slightly elongated obliquely to the shear direction, with some fractures present subparallel to the shear plane inside a grain. In contrast, epidote grains exhibited kink bands and bookshelf gliding textures [26] (Figure 3b). In the sample deformed with an intermediate shear strain $(1<\gamma \leq 2)$, glaucophane grains had elongated, demonstrating cataclastic mosaic fragmented texture. Their rotation was also more oblique to the shear direction than those deformed with low shear strain. However, epidote grains had reduced elongation than glaucophane, exhibiting shear-band-type fragmented texture in this region (Figure $3 c, d)$. In the sample deformed with high shear strain $(\gamma>2)$, all minerals appeared to be elongated and/or flowed subparallel to the shear direction (Figure $3 \mathrm{e}, \mathrm{f}$ ). Relatively large glaucophanes $(\sim 30-50 \mu \mathrm{m})$ were highly elongated, consisting of many small-size grains from 0.5 to $5 \mu \mathrm{m}$. They were in subparallel alignment with the shear direction, exhibiting a cataclastic/granular flow texture. The microstructure of epidote and titanite also presented with similar cataclastic/granular flow textures.

Table 2. Experimental conditions and results for the deformation experiment on epidote blueschist.

\begin{tabular}{|c|c|c|c|c|c|c|c|}
\hline Run \# & P (GPa) & $\mathrm{T}\left({ }^{\circ} \mathrm{C}\right)$ & $\begin{array}{c}\text { Peak } \sigma_{\mathrm{d}} \\
(\mathrm{MPa})\end{array}$ & $\begin{array}{c}\text { Shear } \\
\text { Strain }(\gamma)\end{array}$ & $\begin{array}{c}\text { Shear Strain } \\
\text { Rate }\left(\mathbf{s}^{-1}\right)\end{array}$ & LPO of Gln & LPO of Ep \\
\hline JH148 & 1.2 & $430 \pm 10$ & $700 \pm 20$ & $0.4 \pm 0.02$ & $1.5 \times 10^{-5}$ & Type-1 & Weak fabric \\
\hline JH98b & 1.5 & $500 \pm 10$ & $710 \pm 20$ & $0.6 \pm 0.03$ & $3.4 \times 10^{-5}$ & Type-1 & Weak fabric \\
\hline $\mathrm{JH} 88 \mathrm{~b}$ & 1.5 & $400 \pm 10$ & $800 \pm 20$ & $0.8 \pm 0.03$ & $4.4 \times 10^{-5}$ & Type-1 & Weak fabric \\
\hline $\mathrm{JH} 112 \mathrm{~b}$ & 0.9 & $430 \pm 10$ & $720 \pm 20$ & $0.9 \pm 0.03$ & $4.2 \times 10^{-5}$ & Type-1 & Weak fabric \\
\hline JH94b & 1.5 & $400 \pm 10$ & $900 \pm 20$ & $1.5 \pm 0.06$ & $6.0 \times 10^{-5}$ & Transitional & Weak fabric \\
\hline JH88a & 1.5 & $400 \pm 10$ & $800 \pm 20$ & $2.1 \pm 0.12$ & $1.2 \times 10^{-4}$ & Type-2 & Type-1 \\
\hline JH98a & 1.5 & $500 \pm 10$ & $710 \pm 20$ & $2.4 \pm 0.12$ & $1.4 \times 10^{-4}$ & Type-2 & Type-1 \\
\hline JH150 & 1.2 & $480 \pm 10$ & $680 \pm 20$ & $2.7 \pm 0.15$ & $1.2 \times 10^{-4}$ & Type-2 & Type-1 \\
\hline JH112a & 0.9 & $430 \pm 10$ & $720 \pm 20$ & $2.9 \pm 0.20$ & $1.4 \times 10^{-4}$ & Type-2 & Type-1 \\
\hline $\mathrm{JH} 94 \mathrm{a}$ & 1.5 & $400 \pm 10$ & $900 \pm 20$ & $4.5 \pm 0.38$ & $1.8 \times 10^{-4}$ & Type-2 & Type-2 \\
\hline
\end{tabular}

$\sigma_{\mathrm{d}}$ : differential stress, Gln: glaucophane, and Ep: epidote. 

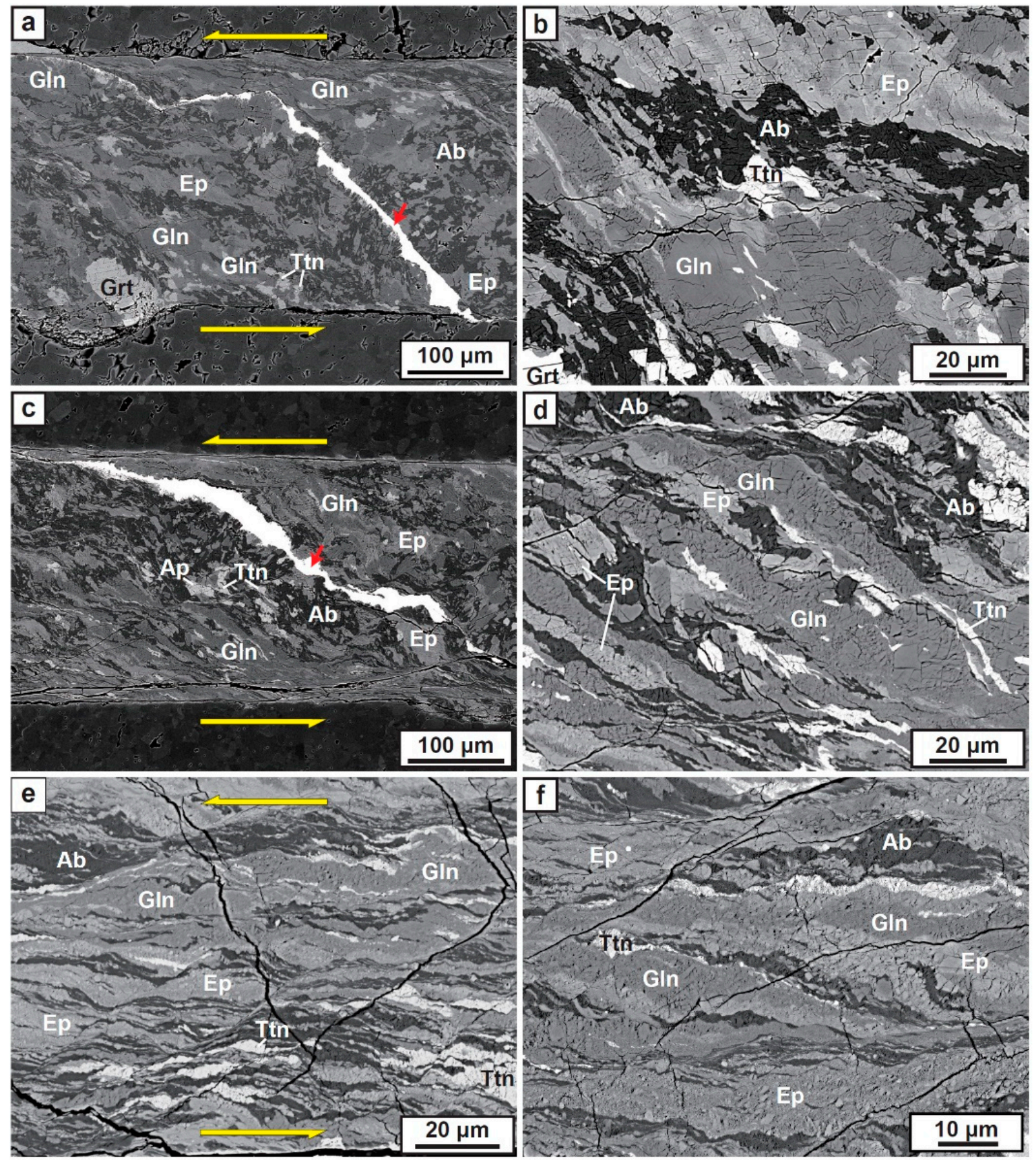

Figure 3. BSE images of deformed samples after simple shear experiments. $(\mathbf{a}, \mathbf{b})$ sample deformed with low shear strain (JH88b, $\gamma=0.8, \mathrm{P}=1.5 \mathrm{GPa}$, and $\left.\mathrm{T}=400{ }^{\circ} \mathrm{C}\right) ;(\mathbf{c}, \mathbf{d})$ sample deformed with intermediate shear strain (JH94b, $\gamma=1.5, \mathrm{P}=1.5 \mathrm{GPa}$, and $\left.\mathrm{T}=400^{\circ} \mathrm{C}\right) ;(\mathbf{e}, \mathbf{f})$ sample deformed with high shear strain (JH94a, $\gamma=4.5, \mathrm{P}=1.5 \mathrm{GPa}$, and $\mathrm{T}=400{ }^{\circ} \mathrm{C}$ ). Long yellow arrows indicate the left-lateral (sinistral) shear sense, and red arrows indicate the Ni strain marker. All samples in the images show the left-lateral (sinistral) shear sense. Gln: glaucophane, Ep: epidote, Ttn: titanite, Ab: albite, Chl: chlorite, Grt: garnet, and Ap: apatite; P: pressure; T = temperature.

In contrast, small grains, originally less than $5 \mu \mathrm{m}$ in size prior to the experiment, appeared to flow exhibiting a thin ductile banded shape (Figure 4). In this region, the ductile shear band representing the C-C' structure and the cataclastic flow textures coexist (Figure 4a). The brittle microfault, indicated by a small offset of the thin banded titanite in the glaucophane, and the ductile elongated shear band of small glaucophane minerals was also observed to coexist (Figure $4 b$ ). 

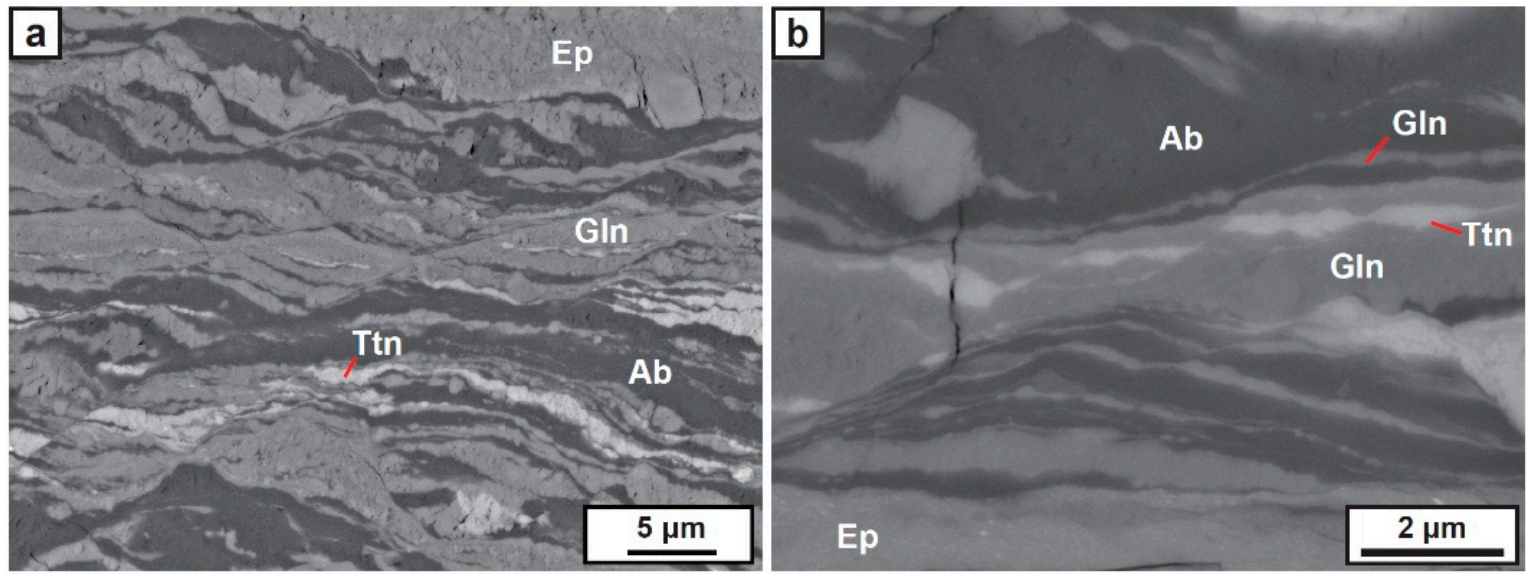

Figure 4. BSE images of sample deformed with high shear strain (JH94a, $\gamma=4.5)$. (a) Ductile shear band showing C-C' structure with cataclastic flow texture; (b) brittle microfault indicated by the titanite offset and ductile elongated shear band of small glaucophane. All images show the left-lateral (sinistral) shear sense. Gln: glaucophane, Ep: epidote, Ttn: titanite, and Ab: albite.

\subsection{Lattice Preferred Orientations of Glaucophane and Epidote}

Figure 5 illustrates the LPOs of glaucophane and epidote. The starting material was set up in the same orientation for all experiments. The initial fabric of glaucophane in the starting material is shown in Figure 5a. It exhibited a weak girdle distribution of the crystallographic [100] axes and the (110) and (010) poles, subnormally aligned with the direction becoming a shear direction, and the [001] axes aligned obliquely to that direction. Based on the pole figures of glaucophane deformed after the experiments (Figure 5b-k), the LPO of glaucophane had altered with increasing shear strain $(\gamma)$. In samples deformed under low shear strain $(\gamma \leq 1)$, the (010) poles of glaucophane had subnormally aligned with the shear plane and the [001] axes were in subparallel alignment with the shear direction; this is defined here as type-1 LPO for glaucophane (Figure $5 \mathrm{~b}-\mathrm{e}$ ). With increasing shear strain between $1<\gamma \leq 2$, the [100] axes, and (010) poles were in subparallel alignment with the shear plane and subnormal to the shear direction, appearing to be a transitional fabric (Figure $5 \mathrm{f}$ ). In samples deformed under high shear strain $(\gamma>2)$, the [100] axes were in subnormally aligned with the shear plane and the [001] axes were in subparallel alignment with the shear direction; this is defined here as type-2 LPO for glaucophane (Figure $5 \mathrm{~g}-\mathrm{k}$ ).

The initial fabric of epidote in the starting material showed that the crystallographic [100] axes were subnormally aligned in the direction becoming a shear direction forming a girdle shape, and the (010) poles were in subparallel alignment with that direction (Figure 5a). After deformation experiments, the LPO of epidote had also altered with increasing shear strain $(\gamma)$. The LPOs of epidote in deformed samples that had undergone low shear strain $(\gamma<2)$ exhibited a weak nonsystematic fabric (Figure $5 \mathrm{~b}-\mathrm{f}$ ). However, in samples deformed under a shear strain between $2<\gamma<4$, the [100] axes of epidote were subnormally aligned with the shear plane, and the (010) poles were in subparallel alignment with the shear direction; this is defined here as type-1 LPO for epidote (Figure $5 \mathrm{~g}-\mathrm{j}$ ). In the sample deformed under a high shear strain of $\gamma=4.5$, the (010) poles of epidote were subnormally aligned with the shear plane, and the [001] axes were in subparallel alignment with the shear direction; this is defined here as type-2 LPO for epidote (Figure 5k). 


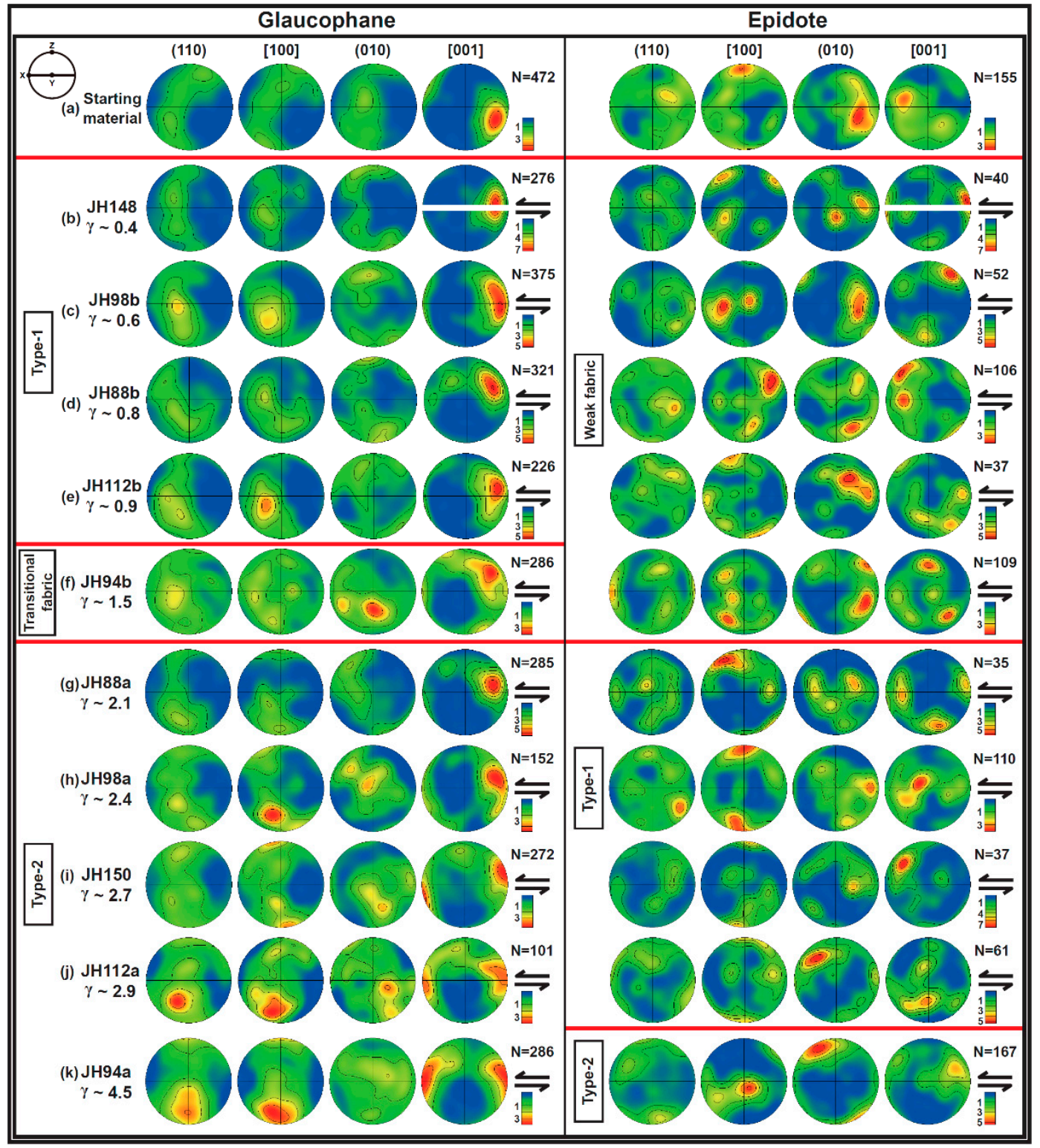

Figure 5. Pole figures of glaucophane and epidote in (a) starting material and (b-k) deformed samples showing LPO presented in the lower hemisphere using an equal-area projection. A half-scatter width of $30^{\circ}$ was used. The X-and Z-directions correspond to the shear direction and the direction normal to the shear plane in the experiment, respectively. White line in pole figure: shear plane; black arrows: shear direction; and $\mathrm{N}$ : the number of grains.

\subsection{Observations of Intracrystalline Deformation Microstructures in Deformed Glaucophane}

EBSD mapping in single glaucophane was undertaken for samples deformed under different shear strains (Figure 6), to observe the intracrystalline deformation microstructures of glaucophane. In glaucophane deformed under a low shear strain of $\gamma=0.8$ at a pressure of $1.5 \mathrm{GPa}$ and a temperature of $400{ }^{\circ} \mathrm{C}(\mathrm{JH} 88 \mathrm{~b})$, the GROD angle map showed that the local misorientation had gradually increased toward the edge of the grain (Figure $6 \mathrm{~b}$ ). In contrast, the KAM map indicated that intracrystalline misorientations were present on the inside and edge of the grain (black arrows in Figure 6c). 

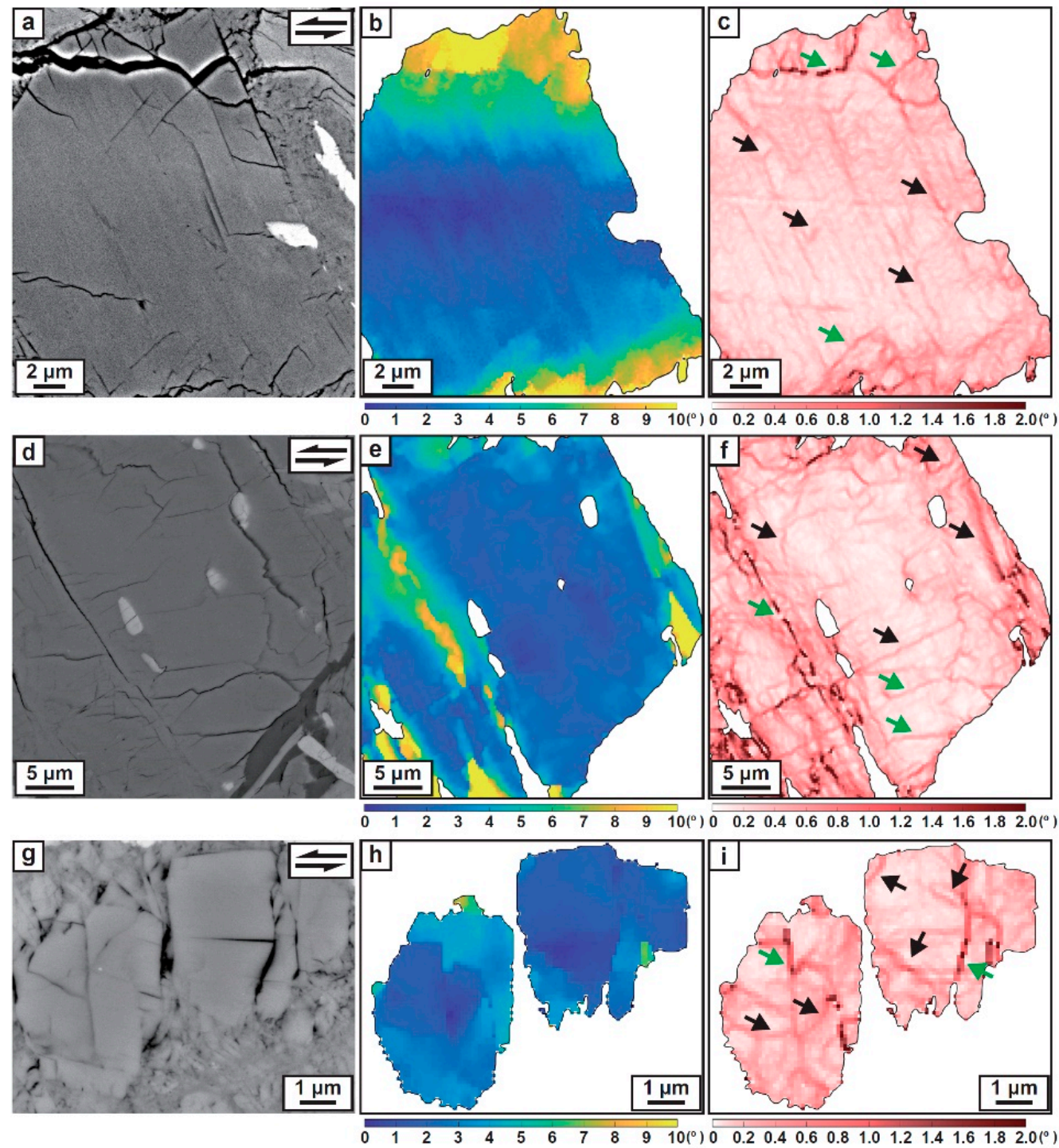

Figure 6. BSE image, grain reference orientation deviation (GROD) angle map (mis2mean), and kernel angle misorientation (KAM) map showing the intracrystalline deformation microstructure of glaucophane deformed under a shear strain of $(\mathbf{a}-\mathbf{c}) \gamma=0.8$ (in JH88b, $\mathrm{P}=1.5 \mathrm{GPa}$, and $\mathrm{T}=400{ }^{\circ} \mathrm{C}$ ), $(\mathbf{d}-\mathbf{f}) \gamma=0.6$ (in JH98b, $\mathrm{P}=1.5 \mathrm{GPa}$, and $\mathrm{T}=500{ }^{\circ} \mathrm{C}$ ), and $(\mathrm{g}-\mathbf{i}) \gamma=4.5$ (in JH94a, $\mathrm{P}=1.5 \mathrm{GPa}$, and $\mathrm{T}=400^{\circ} \mathrm{C}$ ). Black arrows in the BSE images indicate the left-lateral (sinistral) shear sense. Black and green arrows in the KAM map indicate the local plastic strain (i.e., dislocation density or rotation of the lattice) and the tilted crystal orientation by brittle fracture, respectively. Step size of mapping: $(\mathbf{b}, \mathbf{c}) 0.15 \mu \mathrm{m},(\mathbf{e}, \mathbf{f}) 0.2 \mu \mathrm{m}$, and $(\mathbf{h}, \mathbf{i}) 0.1 \mu \mathrm{m}$.

In glaucophane deformed under a low shear strain of $\gamma=0.6$ at a pressure of $1.5 \mathrm{GPa}$ and high temperature of $500{ }^{\circ} \mathrm{C}(\mathrm{JH} 98 \mathrm{~b})$, the GROD angle map illustrated that the high misorientation focused on the fracture in the grain (Figure 6e). However, the KAM map presented well-preserved misorientation lines, irrelevant to the fractures (Figure 6f). For glaucophane deformed under a high shear strain of $\gamma=4.5$ at a pressure of $1.5 \mathrm{GPa}$ and temperature of $400{ }^{\circ} \mathrm{C}(\mathrm{JH} 94 \mathrm{a})$, regardless of the cataclastically comminuted grain, the KAM map showed that several misorientation lines were present in the remaining relatively large grains (Figure 6i). 


\subsection{Observations of Dislocation Microstructures in Deformed Glaucophane and Epidote Using TEM}

Weak-beam dark field (WBDF) and bright-field (BF) images were captured using TEM to observe dislocation microstructures in glaucophane and epidote following the experiments; these are shown in Figures 7 and 8. In glaucophane deformed under a low shear strain $(\gamma \leq 1 ; \gamma=0.6$, in JH98b), WBDF images showed the presence of several dislocation structures. Stacking faults aligned perpendicular to the shear direction (yellow arrow) were observed, in addition to a dislocation loop with a curve toward the shear direction for diffraction vector of $g=101$ (Figure 7a). Straight dislocations aligned perpendicular or oblique to the shear direction were also observed for $\boldsymbol{g}=101$ (Figure 7b). In the glaucophane deformed under a high shear strain $(\gamma>2 ; \gamma=4.5$, in JH94a), WBDF images of relatively large grains showed the presence of several distorted lattice structures (moiré fringe textures) and straight dislocations aligned obliquely to the shear direction (yellow arrow; Figure 7c,d).
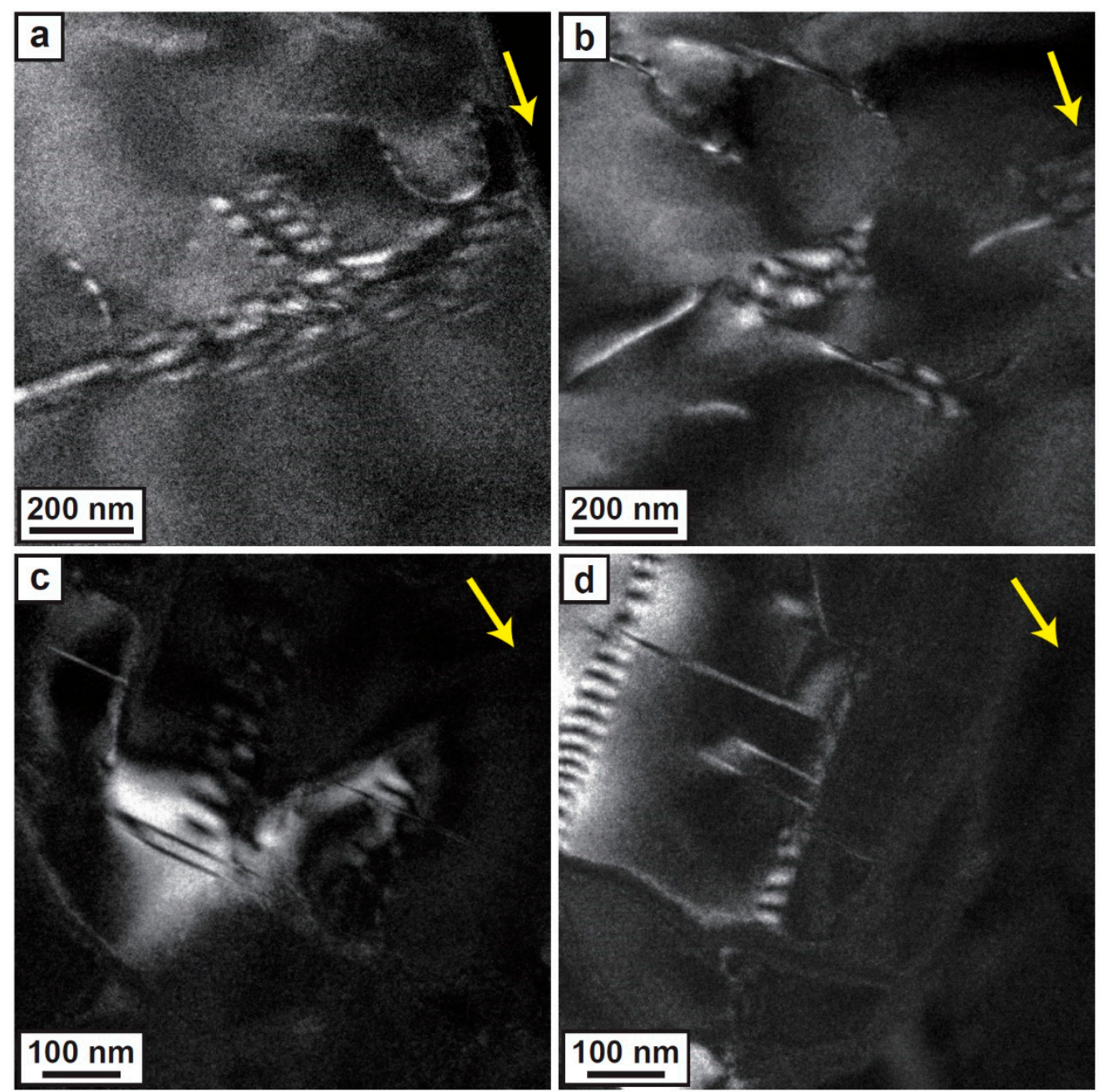

Figure 7. Weak-beam dark field (WBDF) images of glaucophane experimentally deformed with (a,b) low shear strain $(\gamma=0.6)$ at $\mathrm{P}=1.5 \mathrm{GPa}$, and $\mathrm{T}=500{ }^{\circ} \mathrm{C}(\mathrm{JH} 98 \mathrm{~b})$ and with $(\mathbf{c}, \mathrm{d})$ high shear strain $(\gamma=4.5)$ at $\mathrm{P}=1.5 \mathrm{GPa}$, and $\mathrm{T}=400{ }^{\circ} \mathrm{C}(\mathrm{JH} 94 \mathrm{a})$. Yellow arrows indicate shear direction in the images. $\mathrm{P}:$ pressure; and T: temperature. 

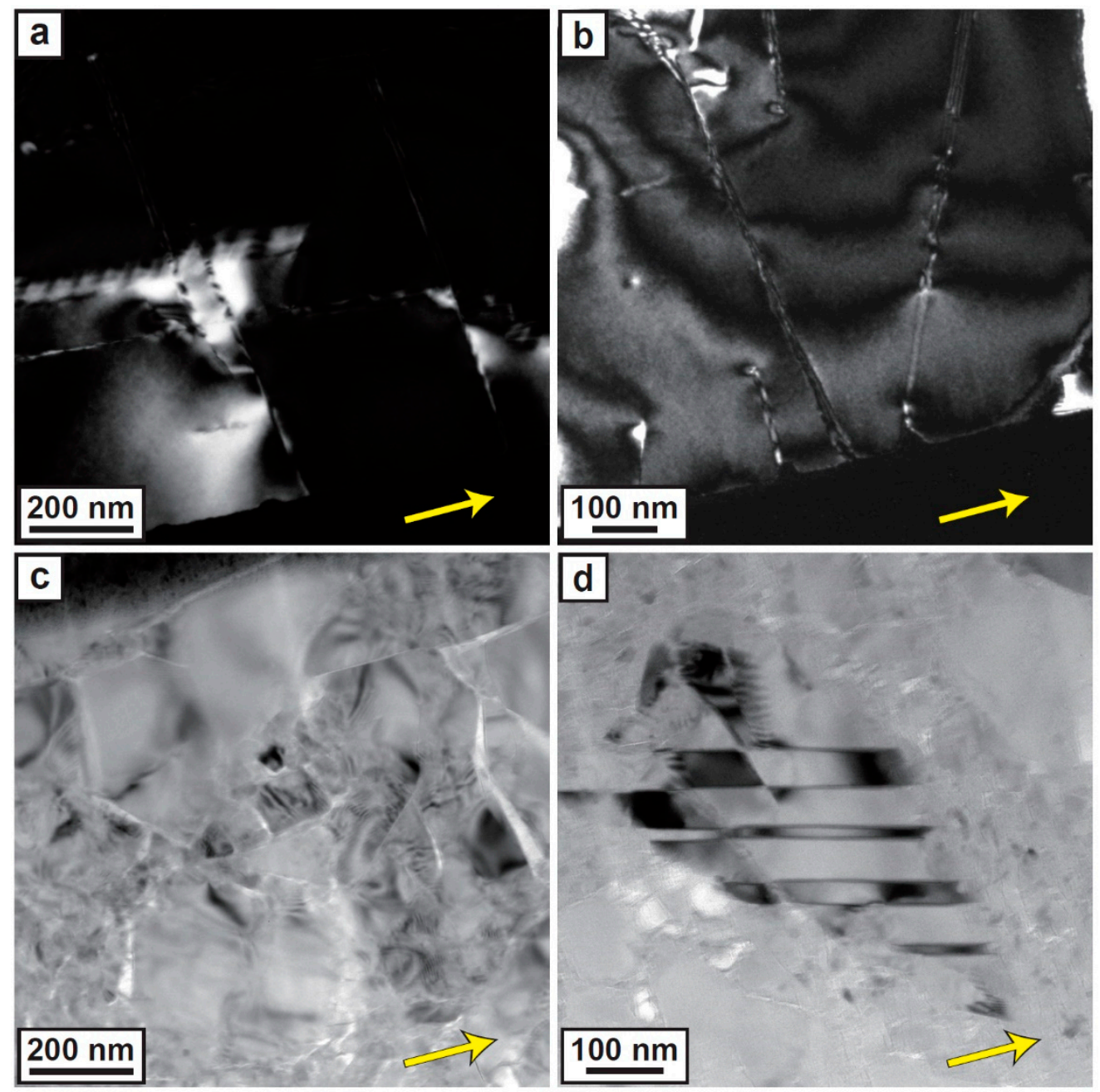

Figure 8. (a,b) Weak-beam dark field (WBDF) images of epidote experimentally deformed under a shear strain of $\gamma=2.4$ at $\mathrm{P}=1.5 \mathrm{GPa}$ and $\mathrm{T}=500{ }^{\circ} \mathrm{C}(\mathrm{JH} 98 \mathrm{a}) ;(\mathbf{c}, \mathrm{d})$ bright-field (BF) images of epidote experimentally deformed under a high shear strain of $\gamma=4.5$ at $\mathrm{P}=1.5 \mathrm{GPa}$ and $\mathrm{T}=400{ }^{\circ} \mathrm{C}(\mathrm{JH} 94 \mathrm{a})$. Yellow arrows indicate the shear direction in the images. P: pressure; and T: temperature.

In epidote deformed under a shear strain between $2<\gamma<4(\gamma=2.4$, JH98a), WBDF images illustrated the presence of several twin boundaries as well as subgrain boundaries aligned parallel or perpendicular to the shear direction (yellow arrow; Figure 8a,b). The BF image of epidote deformed under a high shear strain of $\gamma=4.5$ (JH94a) showed the presence of many distorted lattice structures with brittle failures, similar in texture to glaucophane deformed with a high shear strain (Figure 8c). In addition, a relatively large grain of epidote conserving deformation twins aligned oblique to the shear direction (yellow arrow) was surrounded by grains that were of tens of nanometers size (Figure 8d).

\section{Discussion}

\subsection{LPO Formation and Deformation Mechanisms of Glaucophane}

Although the starting material did not show a clear foliation and lineation in the hand specimen, there was an initial fabric, as shown in Figure 5a. However, the initial LPO of minerals in the starting material was obviously altered with increasing shear strain (Figure $5 b-k$ ). Type- 1 LPOs for glaucophane in samples deformed under a low shear strain $(\gamma \leq 1)$ exhibited (010) poles subnormally aligned with the shear plane and the [001] axes in subparallel alignment with the shear direction (Figure 5b-e); this is rarely observed in natural blueschist. A recent study reported this type-1 LPO for glaucophane 
in weakly deformed (folded) blueschist-facies rock [33]. Previous TEM/HREM study also reported a dislocation slip system of (010)[001] in glaucophane from a blueschist-facies micaschist at a pressure $<1.0 \mathrm{GPa}$ and temperature between 350 and $450{ }^{\circ} \mathrm{C}$ [21]. They suggested that the dislocation glide (or slip) may operate at relatively low temperatures as the Na occupying the $M 4$ site is able to jump into the neighboring empty $A$-site in glaucophane [21]. As the easiest slip systems in chain-silicate structures tend to avoid breaking the Si-O bond [41,42], they concluded that the dislocation glide needs to operate between the Si-O tetrahedral chains; this means the (010) in glaucophane (Figure 9a,b) [21]. This suggestion coincides with the observed dislocation in a single crystal of glaucophane deformed under a low shear strain $(\gamma=0.6)$ in this study (Figure $7 \mathrm{a}, \mathrm{b})$. Various dislocations observed with different diffraction vectors indicate that differing dislocation slip systems were activated by shear deformation. Although this glaucophane was deformed at a relatively high pressure and temperature (i.e., $1.5 \mathrm{GPa}$ and $500{ }^{\circ} \mathrm{C}$, JH98b), the KAM map for glaucophane deformed at a pressure of $1.5 \mathrm{GPa}$ and temperature of $400{ }^{\circ} \mathrm{C}$ showed that intracrystalline deformation (i.e., dislocation glide), also occurs at relatively lower temperature (Figure $6 c$ ). The glaucophane shape slightly elongated oblique to the shear direction is considered a result of the rigid body rotation in a weak plagioclase matrix (Figure 3b). Thus, these results suggest that glaucophane was deformed by the simultaneous rotation of a relatively rigid body with intracrystalline dislocation glide (or slip) forming a strong type-1 LPO under a pressure between 0.9 and $1.5 \mathrm{GPa}$ and a temperature between 400 and $500{ }^{\circ} \mathrm{C}$. This result is consistent with the suggestion from a previous study that rigid body rotation and dynamic recrystallization by dislocation creep are the deformation mechanisms for glaucophane [20]. The glaucophane that had deformed under a shear strain between $1<\gamma \leq 2$, was elongated showing cataclastic and mosaic fragmented texture. This microstructure may indicate that the predominant deformation of glaucophane had converted to brittle behavior as cataclastic flow and rigid body rotation, exhibiting a transitional LPO with a decrease in the fabric strength of glaucophane (Figure $5 \mathrm{f}$ ).

For deformed samples under a high shear strain $(\gamma>2)$, type-2 LPOs of glaucophane exhibited the [100] axes subnormally aligned with the shear plane and the [001] axes in subparallel alignment the shear direction (Figure 5g-k), which have been reported in many natural blueschists [15-18,28-32]. This type-2 LPO of glaucophane is also similar to the type-1 LPO of hornblende [43,44]. A previous TEM/HREM study reported major dislocation glides for (100)[001] and \{110\}[001] in glaucophane from an eclogitic micaschist (at 1.5-1.8 GPa and 550-600 ${ }^{\circ} \mathrm{C}$ ). These are sufficiently active independent slip systems that ensure its ductile behavior during progressive deformation [21]. Other previous studies on natural blueschist have also suggested that dislocation creep was a dominant mechanism in the formation of type-2 glaucophane LPO [17,18]. Based on the TEM investigation in this study, many dislocations and distorted lattice structures were present in a single crystal of glaucophane deformed under a high shear strain $(\gamma=4.5)$ under a pressure of $1.5 \mathrm{GPa}$ and temperature of $400{ }^{\circ} \mathrm{C}(\mathrm{JH} 94 \mathrm{a}$; Figure 7c,d). The KAM map of the deformed grain illustrated many intracrystalline misorientations, irrelevant to the fracture, indicating the activation of dislocations (Figure 6i). High shear strain energy is likely to form a (100) slip plane by breaking the octahedral Mg-O bond, weak M4-site (occupied by $\mathrm{Na}$ ), and $A$-site (empty space; Figure 9a,c). As such, these results suggest that the magnitude of shear strain may be a major cause for changes to dominant slip systems and the formation of different LPOs of glaucophane in the blueschist-facies metamorphic condition. In addition, elongated aggregates of small-size grains with cataclastic/granular flow texture for glaucophane deformed under a strain of $\gamma>2$ (Figure 3e,f), suggest that the type-2 LPO formation may be influenced by simultaneous cataclastic flow deformation of glaucophane. However, originally small grains of glaucophane $(\sim 5 \mu \mathrm{m})$ prior to deformation, appear to flow exhibiting a ductile thin banded shape (Figure 4$)$. These microstructures imply that high shear strain has a different influence on relatively large grains $(\geq 30 \mu \mathrm{m})$ and very fine-grains of glaucophane, causing cataclastic flow deformation and a crystal plastic deformation via dynamic recrystallization [45], respectively. As a result, the rheological contrast between component minerals, shear strain, and grain size may be important factors influencing the deformation mechanisms of glaucophane. 


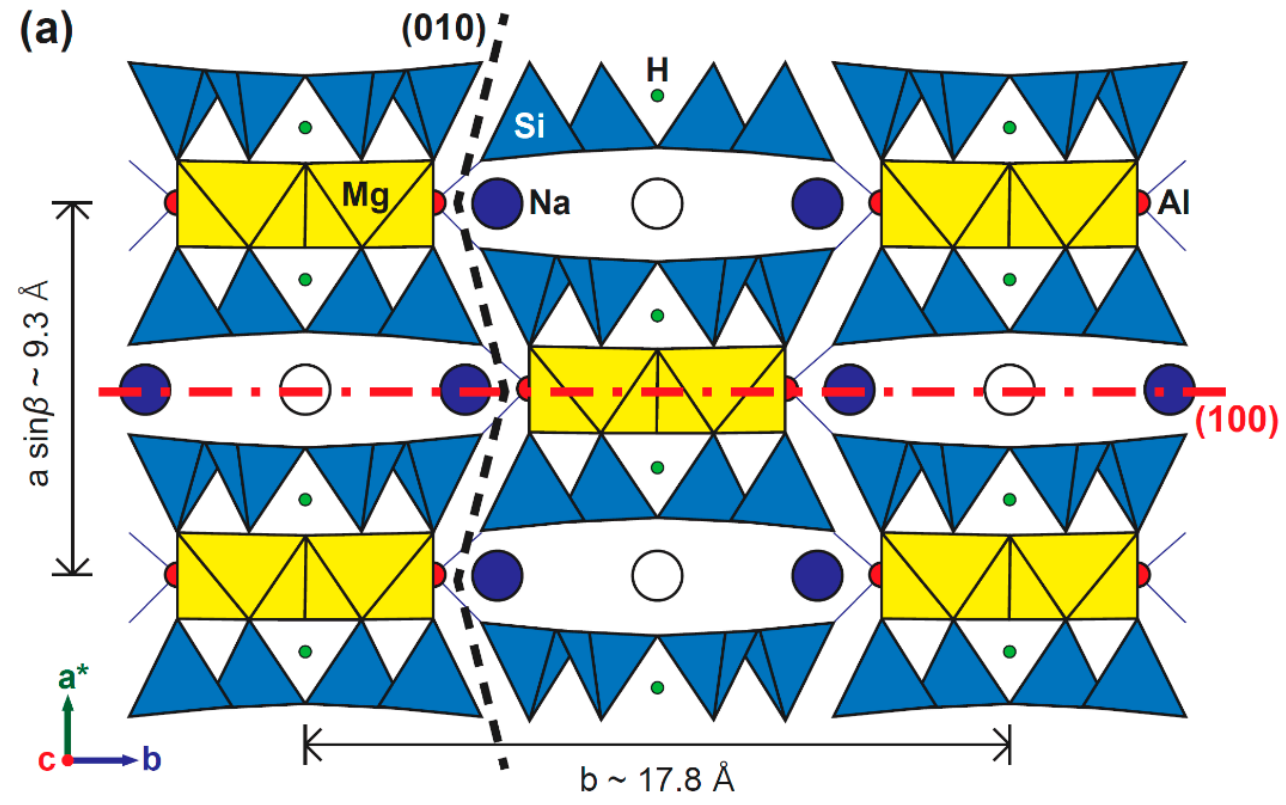

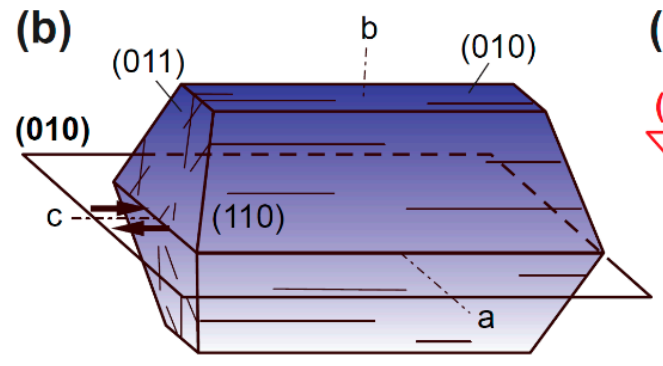

(010)[001]

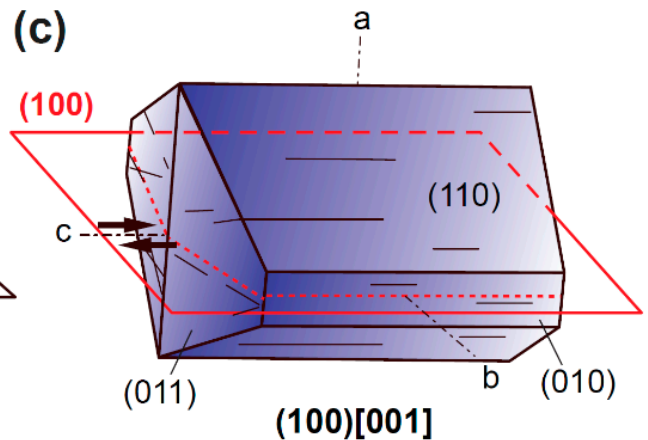

(100)[001]

Figure 9. (a) Simplified glaucophane crystal structure projected onto the (001) plane. Black dashed and red dot-dashed lines indicate the tracks of the easiest slip system planes at low and high shear strain, respectively. Blue tetrahedron: Si-O structure, yellow octahedron: $\mathrm{Mg}-\mathrm{O}$ structure (M1 site), red circle: $\mathrm{Al}$ ( $M 2$ site), green circle: $\mathrm{H}$, blue circle: $\mathrm{Na}$ ( $M 4$ site), and white circle: empty space ( $A$-site). The Mg-O octahedron in the M3 site has been omitted; $(\mathbf{b}, \mathbf{c})$ schematic of the glaucophane crystal form and different dominant slip systems in glaucophane. The transparent truncate sheet and black arrows indicate a dominant slip plane and a dominant slip direction, respectively.

\subsection{LPO Formation and Deformation Mechanisms of Epidote}

Our experimental results showed that epidote in samples deformed under a low shear strain of $\gamma \leq 2$ exhibited mostly weak and nonsystematic LPOs (Figure $5 \mathrm{~b}-\mathrm{f}$ ). This may be due to insufficient strain developing an intracrystalline deformation in epidote as a rigid material. A previous study also reported similar results, revealing that low shear strain $(\gamma=2)$ was insufficient to produce a strong preferred orientation of experimentally deformed epidote mineral as a relatively rigid particle in a deformed plagioclase matrix at a pressure of $1.5 \mathrm{GPa}$ and a temperature of $750{ }^{\circ} \mathrm{C}$ [27]. In contrast, the type-1 LPO of epidote in samples deformed under a shear strain between $2<\gamma<4$ (Figure $5 \mathrm{~g}-\mathrm{j}$ ) and type-2 LPO of epidote deformed under a shear strain of $\gamma=4.5$ (Figure $5 \mathrm{k}$ ) were different from previously reported LPOs $[16,17,28-30,33,35]$. However, a previous TEM and HREM investigation reported stacking faults on (100) and lamellar twins on (100) as the easiest shearing planes of epidote mineral (clinozoisite and zoisite) [34]. Other studies have also observed deformation twin lamellae on (100) of clinozoisite in eclogite $[24,25]$. This plane was consistent with a relatively weak bond for the $A$-site (occupied by Ca) and M3-site (occupied by Al-Fe ${ }^{3+}$; Figure 10a,b) [46]. On TEM observations of 
the epidote crystal deformed under a shear strain between $2<\gamma<4$ ( $\gamma=2.4$, JH98a), several aligned dislocations, subgrain boundaries, and deformation twins were present (Figure 8a,b). This suggests that dislocation glide or slip may play a major role in the formation of type-1 LPO for epidote. This result is consistent with deformation processes of epidote group minerals as suggested by Franz and Liebscher [26]; these are either dislocation glide or sliding on the cleavage by fracturing in naturally deformed rocks. On the contrary, another previous study suggested a rigid body rotation as an LPO formation mechanism for epidote group minerals in metabasite rocks through two potential processes. Firstly, where zoisite minerals are deformed by shearing parallel to the (100) cleavage planes and rotated to align with the (100) plane subparallel to foliation. Secondly, where they are deformed by stretching in the [010] axes, resulting in boudinaged crystals in subparallel alignment with lineation, and the (100) plane is simultaneously aligned, subparallel to foliation [23]. As the epidote is a relatively rigid mineral in this blueschist sample, a rigid body rotation may also be a major process for the development of type-1 LPO.

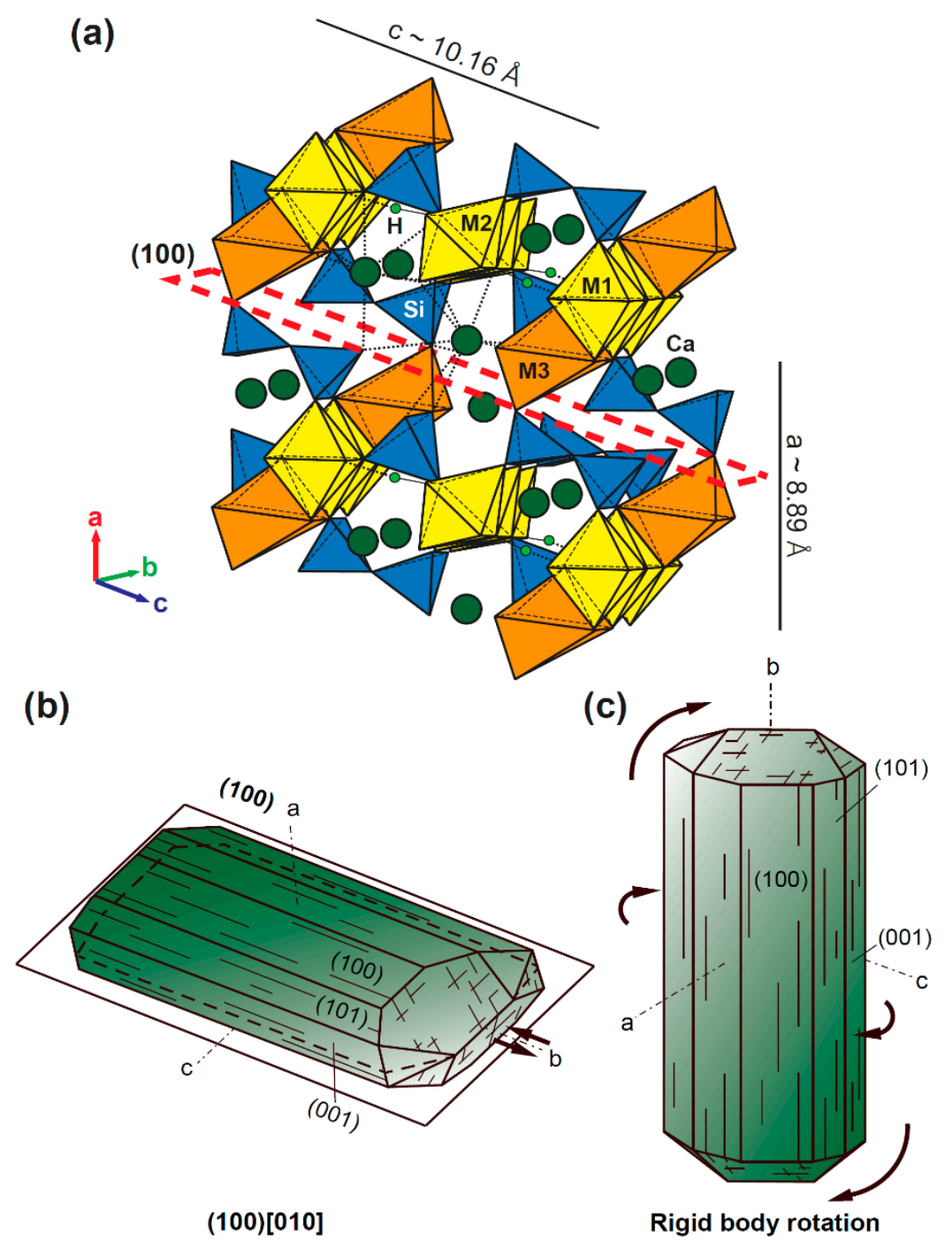

Figure 10. (a) Simplified epidote crystal structure. Red dashed rectangular indicate the tracks of the easiest (100) slip plane. Blue tetrahedron: Si-O structure, yellow octahedron: Al-O structure (M1 and M2 site), orange octahedron: $\mathrm{Al}-\mathrm{Fe}^{3+}$ substitution-O (M3 site), blue circle: $\mathrm{H}$, and green circle: $\mathrm{Ca}(A 1$ and $A 2$ site); (b,c) schematic of the epidote crystal form with different behavior by slip. The transparent truncate sheet and black arrows in (b) indicate a dominant slip plane and a dominant slip direction, respectively. Black arrows in (c) indicate a direction of rigid body rotation by shear strain. 
The type-2 LPO of epidote has not yet been reported. A previous experimental study has suggested that epidote minerals are deformed by granular flow and diffusion-assisted grain boundary sliding at relatively high shear strain $(\gamma=4.5$ and 7.5$)$, thereby developing shear band textures at a pressure of $1.5 \mathrm{GPa}$ and temperature of $750{ }^{\circ} \mathrm{C}$ [27]. Based on the TEM investigation in this study, relatively large grains of epidote conserving deformation twins surrounded by nanocrystalline grains were observed in the sample deformed under a shear strain of $\gamma>4(\gamma=4.5$, JH94a; Figure 8c,d). These microstructures indicate that cataclastic/granular flow with rigid body rotation may play an important role in the formation of type-2 LPO of epidote (Figure 10c). In contrast, a previous study on naturally bent and kinked epidote crystal suggested that all $\{100\},\{010\},\{001\}$ planes play a major role in the deformation of epidote group minerals, either as dislocation slip planes or as cleavage planes [26]. Thus, type-1 and type-2 LPOs of epidote were likely to have been developed by dislocation creep and cataclastic flow with rigid body rotation due to rheological contrasts with other minerals. Further studies on the slip system of epidote are required at various pressure and temperature conditions to better understand the epidote LPOs/slip systems transition.

\subsection{Implications for Deformation Mechanisms of Epidote Blueschist in a Warm Subduction Zone}

The EBSD analysis and TEM investigation of experimental specimens revealed that glaucophane and epidote, major constituent minerals of epidote blueschist, had deformed simultaneously through brittle and ductile behavior at a pressure between 0.9 and $1.5 \mathrm{GPa}$ and a temperature between 400 and $500{ }^{\circ} \mathrm{C}$. These results indicate that epidote blueschist is likely to undergo deformation in the brittle-ductile regime. The nonlocalized cataclastic flow in the deformed sample may be attributed to the deformation microstructures in the semi-brittle regime following the brittle-ductile transition [47,48]. Thus, a brittle-ductile transition of glaucophane is likely to occur under a pressure of 1.0-1.5 GPa at $400-500{ }^{\circ} \mathrm{C}$ in epidote blueschist. This result is relatively consistent with previous suggestions that glaucophane may be deformed under a ductile regime (i.e., dislocation creep), in natural epidote blueschist at the pressures of $\sim 0.5-2.0 \mathrm{GPa}[16,17,35]$. A previous experimental study on lawsonite blueschist also suggested that the brittle-ductile transition of glaucophane is likely to occur at a pressure of $\sim 2 \mathrm{GPa}$ and temperatures between 400 and $500{ }^{\circ} \mathrm{C}$ [49]. One may argue that the cataclastic deformation microstructure in this study was produced by the deformation of the sample at a fast strain rate. However, there are also examples showing cataclastic deformation microstructures in natural blueschists and blueschist-facies metamorphic rocks that were deformed at low strain rates [50,51]. In addition, experimental results have suggested that while the microstructure of epidote is similar to glaucophane, the shear strain required to change the LPO of epidote appears to be larger than glaucophane (Figure 11). This is likely a result of the strength contrast between glaucophane and epidote, as deformation is concentrated and strain is localized on relatively weaker minerals [52]. As a result, epidote blueschist that exists in a warm subduction zone may be deformed under the coexistence of brittle and ductile regimes due to the rheological contrast between constituent minerals under stable pressure and temperature conditions. 


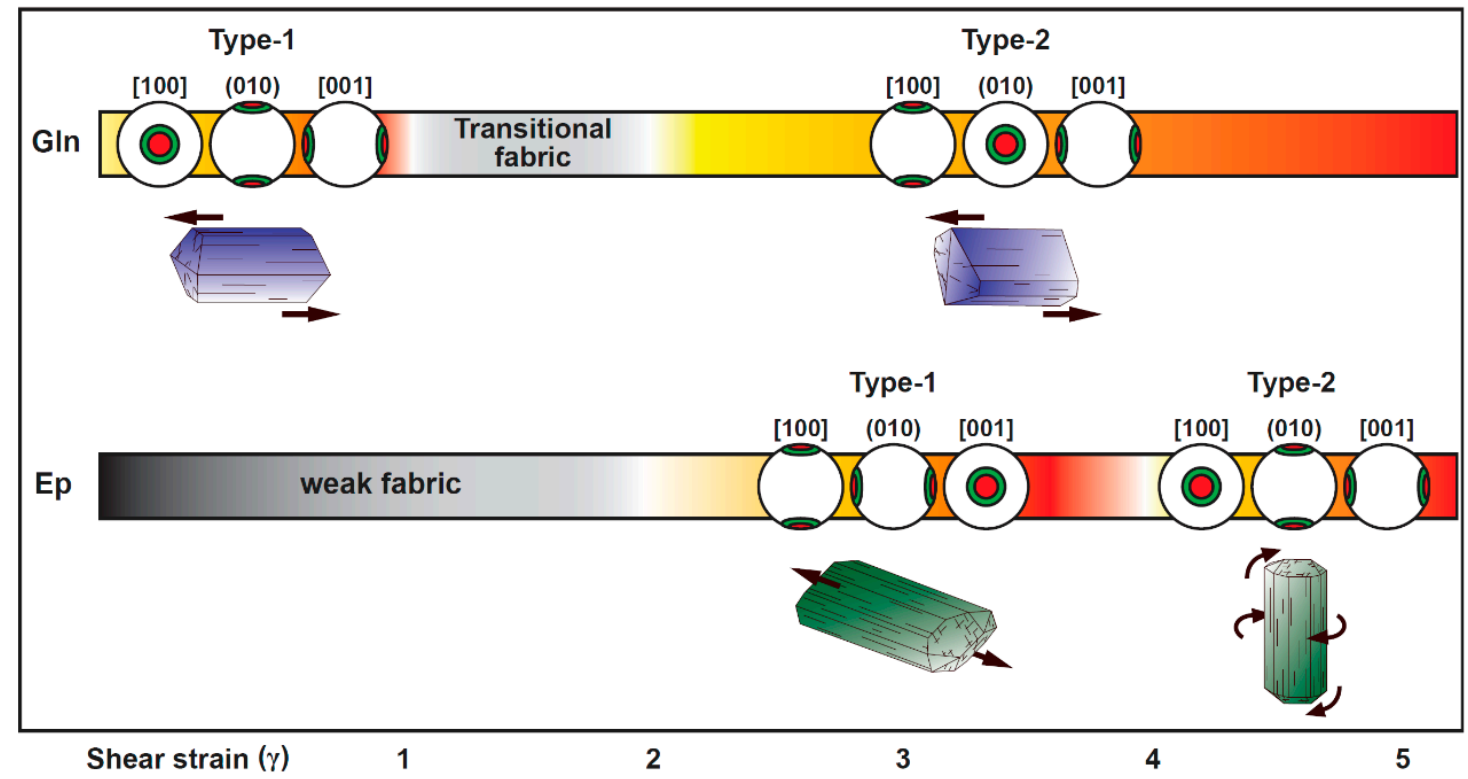

Figure 11. Schematic of the development of LPOs of glaucophane and epidote with increasing shear strain. Gln: glaucophane; and Ep: epidote.

\subsection{Implications for Seismic Anisotropy of Subducting Slab in a Subduction Zone}

The seismic anisotropy of shear waves in the forearc region of the subduction zone has been mainly observed by SKS waves propagating through the anisotropic mediums and throughout the area subperpendicular to the Earth's surface [53]. As SKS anisotropic data are measured by path integration, the source for the splitting of S-waves has been regarded as multiple anisotropic layers. Among these layers, the mantle wedge and subslab mantle have been considered as the main anisotropic mediums because of the large volume proportions in the lithosphere [54]. Specifically, the B-type LPO of olivine in the mantle wedge has been suggested as a cause for the change from the trench-normal to trench-parallel polarization direction of the fast shear wave in the forearc region $[55,56]$. However, subducting oceanic crust is also a potential anisotropic layer where many elastically anisotropic minerals are stable $[3,12]$. Therefore, recent studies have suggested that type-2 LPO of glaucophane may affect the trench-parallel seismic anisotropy of the forearc region, where the subducting slab has a high dip angle [15-18]. This is because the propagation velocity of the fast S-wave (Vs1) through the b-and c-axes of the glaucophane is much faster than that through an a-axis in glaucophane. In contrast, the type-1 LPO of glaucophane may contribute to the trench-normal polarization direction regardless of the subducting angle because the b- and c-axes are continuously aligned parallel to the shear direction in the subducting slab with different dip angles. The type- 1 and type-2 LPOs of epidote in this study have not yet been reported in natural samples. However, if epidote with type-1 LPO exists in the subducting slab, this LPO may also influence the trench-normal seismic anisotropy regardless of whether the subducting angle due to the Vs1 through the a- and b-axes of the epidote is much faster than that through the c-axis. In contrast, if epidote with type-2 LPO exists in the subducting slab, this LPO may contribute to the trench-parallel seismic anisotropy where the subducting slab has a low dip angle. However, further research is needed to determine whether these LPO types of epidote could exist in natural blueschist. Consequently, different types of LPOs for glaucophane and epidote may contribute to the different seismic anisotropies of the forearc region in the subduction zone: type-1 LPOs of glaucophane and epidote can contribute to the trench-normal seismic anisotropy in the subducting slab, and type-2 LPOs of glaucophane and epidote may affect the trench-parallel seismic anisotropy of the forearc region, where the subducting slab has a high dip angle and a low dip angle, respectively. 


\section{Conclusions}

We conducted deformation experiments of epidote blueschist in simple shear using the modified Griggs apparatus to understand deformation microstructures, the development of LPOs, and deformation mechanisms of glaucophane and epidote over a warm subducting slab. After the experiments, two different types of glaucophane and epidote LPOs were developed by different mechanisms depending on the magnitude of shear strain and grain size. TEM observations and EBSD mapping of glaucophane suggest that the LPO of glaucophane was developed by dislocation creep under a shear strain of $0.4 \leq \gamma \leq 4.5$. At a shear strain of $\gamma>2$, cataclastic/granular flow microstructures were observed in large grains. At a high shear strain of $\gamma=4.5$, thin ductile shear bands were observed in the small grains. Our experimental results suggest that the brittle-ductile transition of glaucophane likely occurs at epidote blueschist-facies metamorphic conditions. On the other hand, intracrystalline microstructures in epidote such as subgrain boundaries and twins revealed by TEM observations suggest that the LPO of epidote was developed by dislocation creep under a shear strain of $2<\gamma<4$. However, the development of the LPO of epidote under a high shear strain $(\gamma>4)$ is considered to be influenced by cataclastic flow with rigid body rotation because epidote is more rigid than other minerals in the matrix. Therefore, our data suggest that the magnitude of shear strain, grain size, and rheological contrast between component minerals are important factors influencing the deformation mechanisms and development of LPOs of glaucophane and epidote. However, there is a need for further studies on the fabric transition of epidote under various pressure and temperature conditions.

Author Contributions: Conceptualization, Y.P. and H.J.; methodology, Y.P. and S.J.; software, Y.P.; validation, Y.P. and H.J.; formal analysis, Y.P.; investigation, Y.P. and S.J.; resources, H.J.; data curation, Y.P.; writing-original draft preparation, Y.P.; writing-review and editing, Y.P., H.J., and S.J.; visualization, Y.P.; supervision, H.J.; project administration, H.J.; funding acquisition, H.J. All authors have read and agreed to the published version of the manuscript.

Funding: This research was funded by the Mid-career Research Program through the National Research Foundation of Korea (NRF: 2020R1A2C2003765) to H.J.

Acknowledgments: The authors are grateful to the anonymous reviewers whose suggestions and comments have notably improved the manuscript.

Conflicts of Interest: The authors declare no conflict of interest.

\section{References}

1. Evans, B.W. Phase relations of epidote-blueschists. Lithos 1990, 25, 3-23. [CrossRef]

2. Peacock, S.M. The importance of blueschist eclogite dehydration reactions in subducting oceanic crust. Geol. Soc. Am. Bull. 1993, 105, 684-694. [CrossRef]

3. Schmidt, M.W.; Poli, S. Experimentally based water budgets for dehydrating slabs and consequences for arc magma generation. Earth Planet. Sci. Lett. 1998, 163, 361-379. [CrossRef]

4. Agard, P.; Yamato, P.; Jolivet, L.; Burov, E. Exhumation of oceanic blueschists and eclogites in subduction zones: Timing and mechanisms. Earth-Sci. Rev. 2009, 92, 53-79. [CrossRef]

5. Ernst, W. Tectonic history of subduction zones inferred from retrograde blueschist PT paths. Geology 1988, 16, 1081-1084. [CrossRef]

6. Tsujimori, T.; Ernst, W.G. Lawsonite blueschists and lawsonite eclogites as proxies for palaeo-subduction zone processes: A review. J. Metamorph. Geol. 2014, 32, 437-454. [CrossRef]

7. Hasegawa, A.; Nakajima, J.; Kita, S.; Okada, T.; Matsuzawa, T.; Kirby, S.H. Anomalous deepening of a belt of intraslab earthquakes in the Pacific slab crust under Kanto, central Japan: Possible anomalous thermal shielding, dehydration reactions, and seismicity caused by shallower cold slab material. Geophys. Res. Lett. 2007, 34. [CrossRef]

8. Kawakatsu, H.; Watada, S. Seismic evidence for deep-water transportation in the mantle. Science 2007, 316, 1468-1471. [CrossRef]

9. Tsuji, Y.; Nakajima, J.; Hasegawa, A. Tomographic evidence for hydrated oceanic crust of the Pacific slab beneath northeastern Japan: Implications for water transportation in subduction zones. Geophys. Res. Lett. 2008, 35. [CrossRef] 
10. Abers, G.A.; Nakajima, J.; van Keken, P.E.; Kita, S.; Hacker, B.R. Thermal-petrological controls on the location of earthquakes within subducting plates. Earth Planet. Sci. Lett. 2013, 369-370, 178-187. [CrossRef]

11. Hirose, F.; Nakajima, J.; Hasegawa, A. Three-dimensional seismic velocity structure and configuration of the Philippine Sea slab in southwestern Japan estimated by double-difference tomography. J. Geophys. Res. 2008, 113, 09311-09326. [CrossRef]

12. Hacker, B.R.; Abers, G.A.; Peacock, S.M. Subduction factory 1. Theoretical mineralogy, densities, seismic wave speeds, and H2O contents. J. Geophys. Res. Solid Earth 2003, 108, 2021-2026, 2029. [CrossRef]

13. Audet, P.; Kim, Y. Teleseismic constraints on the geological environment of deep episodic slow earthquakes in subduction zone forearcs: A review. Tectonophysics 2016, 670, 1-15. [CrossRef]

14. Audet, P.; Bostock, M.G.; Boyarko, D.C.; Brudzinski, M.R.; Allen, R.M. Slab morphology in the Cascadia fore arc and its relation to episodic tremor and slip. J. Geophys. Res. 2010, 115. [CrossRef]

15. Cao, Y.; Jung, H. Seismic properties of subducting oceanic crust: Constraints from natural lawsonite-bearing blueschist and eclogite in Sivrihisar Massif, Turkey. Phys. Earth Planet. Inter. 2016, 250, 12-30. [CrossRef]

16. Cao, Y.; Jung, H.; Song, S. Petro-fabrics and seismic properties of blueschist and eclogite in the North Qilian suture zone, NW China: Implications for the low-velocity upper layer in subducting slab, trench-parallel seismic anisotropy, and eclogite detectability in the subduction z. J. Geophys. Res. Solid Earth 2013, 118, 3037-3058. [CrossRef]

17. Kim, D.; Katayama, I.; Michibayashi, K.; Tsujimori, T. Deformation fabrics of natural blueschists and implications for seismic anisotropy in subducting oceanic crust. Phys. Earth Planet. Inter. 2013, 222, 8-21. [CrossRef]

18. Cao, Y.; Jung, H.; Song, S. Microstructures and petro-fabrics of lawsonite blueschist in the North Qilian suture zone, NW China: Implications for seismic anisotropy of subducting oceanic crust. Tectonophysics 2014, 628, 140-157. [CrossRef]

19. Ildefonse, B.; Lardeaux, J.-M.; Caron, J.-M. The behavior of shape preferred orientations in metamorphic rocks: Amphiboles and jadeites from the Monte Mucrone area (Sesia-Lanzo zone, Italian Western Alps). J. Struct. Geol. 1990, 12, 1005-1011. [CrossRef]

20. Zucali, M.; Chateigner, D.; Dugnani, M.; Lutterotti, L.; Ouladdiaf, B. Quantitative texture analysis of glaucophanite deformed under eclogite facies conditions (Sesia-Lanzo Zone, Western Alps): Comparison between X-ray and neutron diffraction analysis. Geol. Soc. Lond. Spec. Publ. 2002, 200, 239-253. [CrossRef]

21. Reynard, B.; Gillet, P.; Willaime, C. Deformation mechanisms in naturally deformed glaucophanes: A TEM and HREM study. Eur. J. Mineral. 1989, 1, 611-624. [CrossRef]

22. Wassmann, S.; Stöckhert, B. Rheology of the plate interface-Dissolution precipitation creep in high pressure metamorphic rocks. Tectonophysics 2013, 608, 1-29. [CrossRef]

23. Brunsmann, A.; Franz, G.; Erzinger, J.; Landwehr, D. Zoisite-and clinozoisite-segregations in metabasites (Tauern Window, Austria) as evidence for high-pressure fluid-rock interaction. J. Metamorph. Geol. 2000, 18, 1-22. [CrossRef]

24. Müller, W.F.; Franz, G. Unusual deformation microstructures in garnet, titanite and clinozoisite from an eclogite of the Lower Schist Cover, Tauern Window, Austria. Eur. J. Mineral. 2004, 16, 939-944. [CrossRef]

25. Müller, W.F.; Franz, G. TEM-microstructures in omphacite and other minerals from eclogite near to a thrust zone; the Eclogite Zone-Venediger nappe area, Tauern Window, Austria. Neues Jahrb. Mineral.-Abh. J. Mineral. Geochem. 2008, 184, 285-298.

26. Franz, G.; Liebscher, A. Physical and Chemical Properties of the Epidote Minerals-An Introduction-. Rev. Mineral. Geochem. 2004, 56, 1-81. [CrossRef]

27. Stünitz, H.; Tullis, J. Weakening and strain localization produced by syn-deformational reaction of plagioclase. Int. J. Earth Sci. 2001, 90, 136-148. [CrossRef]

28. Bezacier, L.; Reynard, B.; Bass, J.D.; Wang, J.; Mainprice, D. Elasticity of glaucophane, seismic velocities and anisotropy of the subducted oceanic crust. Tectonophysics 2010, 494, 201-210. [CrossRef]

29. Ha, Y.; Jung, H.; Raymond, L.A. Deformation fabrics of glaucophane schists and implications for seismic anisotropy: The importance of lattice preferred orientation of phengite. Int. Geol. Rev. 2018, 61, 720-737. [CrossRef]

30. Fujimoto, Y.; Kono, Y.; Hirajima, T.; Kanagawa, K.; Ishikawa, M.; Arima, M. P-wave velocity and anisotropy of lawsonite and epidote blueschists: Constraints on water transportation along subducting oceanic crust. Phys. Earth Planet. Inter. 2010, 183, 219-228. [CrossRef] 
31. Kim, D.; Katayama, I.; Michibayashi, K.; Tsujimori, T. Rheological contrast between glaucophane and lawsonite in naturally deformed blueschist from Diablo Range, California. Isl. Arc 2013, 22, 63-73. [CrossRef]

32. Teyssier, C.; Whitney, D.L.; Toraman, E.; Seaton, N.C.A. Lawsonite vorticity and subduction kinematics. Geology 2010, 38, 1123-1126. [CrossRef]

33. Cossette, É.; Schneider, D.; Audet, P.; Grasemann, B.; Habler, G. Seismic properties and mineral crystallographic preferred orientations from EBSD data: Results from a crustal-scale detachment system, Aegean region. Tectonophysics 2015, 651-652, 66-78. [CrossRef]

34. Ray, N.J.; Putnis, A.; Gillet, P. Polytypic relationship between clinozoisite and zoisite. Bull. Mineral. 1986, 109, 667-685. [CrossRef]

35. Cao, Y.; Song, S.; Niu, Y.L.; Jung, H.; Jin, Z.M. Variation of mineral composition, fabric and oxygen fugacity from massive to foliated eclogites during exhumation of subducted ocean crust in the North Qilian suture zone, NW China. J. Metamorph. Geol. 2011, 29, 699-720. [CrossRef]

36. Malatesta, C.; Crispini, L.; Federico, L.; Capponi, G.; Scambelluri, M. The exhumation of high pressure ophiolites (Voltri Massif, Western Alps): Insights from structural and petrologic data on metagabbro bodies. Tectonophysics 2012, 568-569, 102-123. [CrossRef]

37. Vignaroli, G.; Rossetti, F.; Bouybaouene, M.; Massonne, H.J.; Theye, T.; Faccenna, C.; Funiciello, R. A counter-clockwise P-T path for the Voltri Massif eclogites (Ligurian Alps, Italy). J. Metamorph. Geol. 2005, 23, 533-555. [CrossRef]

38. Prior, D.J.; Boyle, A.P.; Brenker, F.; Cheadle, M.C.; Day, A.; Lopez, G.; Peruzzo, L.; Potts, G.J.; Reddy, S.; Spiess, R. The application of electron backscatter diffraction and orientation contrast imaging in the SEM to textural problems in rocks. Am. Mineral. 1999, 84, 1741-1759. [CrossRef]

39. Lloyd, G.E. Atomic number and crystallographic contrast images with the SEM: A review of backscattered electron techniques. Mineral. Mag. 1987, 51, 3-19. [CrossRef]

40. Bachmann, F.; Hielscher, R.; Schaeben, H. Grain detection from 2d and 3d EBSD data-Specification of the MTEX algorithm. Ultramicroscopy 2011, 111, 1720-1733. [CrossRef]

41. Nicolas, A.; Poirier, J.P. Crystalline Plasticity and Solid State Flow in Metamorphic Rocks; John Wiley \& Sons: Hoboken, NJ, USA, 1976; p. 444.

42. van Duysen, J.C.; Doukhan, J.C. Room temperature microplasticity of a spodumene LiAlSi2O6. Phys. Chem. Miner. 1984, 10, 125-132. [CrossRef]

43. Ko, B.; Jung, H. Crystal preferred orientation of an amphibole experimentally deformed by simple shear. Nat. Commun. 2015, 6, 1-10. [CrossRef] [PubMed]

44. Jung, H. Crystal preferred orientations of olivine, orthopyroxene, serpentine, chlorite, and amphibole, and implications for seismic anisotropy in subduction zones: A review. Geosci. J. 2017, 21, 985-1011. [CrossRef]

45. Drury, M.R.; Urai, J.L. Deformation-related recrystallization processes. Tectonophysics 1990, 172, $235-253$. [CrossRef]

46. Deer, W.A.; Howie, R.A.; Zussman, J. Rock-Forming Minerals: Disilicates and Ring Silicates, 2nd ed.; Geological Society of London: London, UK, 1986; p. 629.

47. Kohlstedt, D.; Evans, B.; Mackwell, S. Strength of the lithosphere: Constraints imposed by laboratory experiments. J. Geophys. Res. Solid Earth 1995, 100, 17587-17602. [CrossRef]

48. Karato, S.-I. Deformation of Earth Materials: An Introduction to the Rheology of Solid Earth; Cambridge University Press: Cambridge, UK, 2008; p. 463.

49. Kim, D.; Katayama, I.; Wallis, S.; Michibayashi, K.; Miyake, A.; Seto, Y.; Azuma, S. Deformation microstructures of glaucophane and lawsonite in experimentally deformed blueschists: Implications for intermediate-depth intraplate earthquakes. J. Geophys. Res. Solid Earth 2015, 120, 1229-1242. [CrossRef]

50. Balestro, G.; Festa, A.; Tartarotti, P. Tectonic significance of different block-in-matrix structures in exhumed convergent plate margins: Examples from oceanic and continental HP rocks in Inner Western Alps (Northwest Italy). Int. Geol. Rev. 2014, 57, 581-605. [CrossRef]

51. Ukar, E.; Cloos, M. Cataclastic deformation and metasomatism in the subduction zone of mafic blocks-in-mélange, San Simeon, California. Lithos 2019, 346-347, 105116. [CrossRef]

52. Ebert, A.; Herwegh, M.; Pfiffner, A. Cooling induced strain localization in carbonate mylonites within a large-scale shear zone (Glarus thrust, Switzerland). J. Struct. Geol. 2007, 29, 1164-1184. [CrossRef] 
53. Long, M.D. Constraints on Subduction Geodynamics from Seismic Anisotropy. Rev. Geophys. 2013, 51, 76-112. [CrossRef]

54. Long, M.D.; Becker, T.W. Mantle dynamics and seismic anisotropy. Earth Planet. Sci. Lett. 2010, 297, 341-354. [CrossRef]

55. Jung, H.; Karato, S.-I. Water-induced fabric transitions in olivine. Science 2001, 293, 1460-1463. [CrossRef] [PubMed]

56. Karato, S.-I.; Jung, H.; Katayama, I.; Skemer, P. Geodynamic significance of seismic anisotropy of the upper mantle: New insights from laboratory studies. Annu. Rev. Earth Planet. Sci. 2008, 36, 59-95. [CrossRef] 